\title{
The Application of Catalytic Processes on the Production of Algae-Based Biofuels: A Review
}

\author{
Antonio Zuorro $^{1, *(\mathbb{D})}$, Janet B. García-Martínez ${ }^{2} \mathbb{D}$ and Andrés F. Barajas-Solano ${ }^{2}$ (D) \\ 1 Department of Chemical Engineering, Materials and Environment, Sapienza University, Via Eudossiana 18, \\ 00184 Roma, Italy \\ 2 Department of Environmental Sciences, Universidad Francisco de Paula Santander, Av. Gran Colombia \\ No. 12E-96, Cucuta 540003, Colombia; janetbibianagm@ufps.edu.co (J.B.G.-M.); \\ andresfernandobs@ufps.edu.co (A.F.B.-S.) \\ * Correspondence: antonio.zuorro@uniroma1.it
}

Citation: Zuorro, A.; García-Martínez, J.B.; Barajas-Solano, A.F. The Application of Catalytic Processes on the Production of Algae-Based Biofuels: A Review. Catalysts 2021, 11, 22. https://doi.org/10.3390/catal 11010022

Received: 25 September 2020 Accepted: 27 November 2020 Published: 28 December 2020

Publisher's Note: MDPI stays neutral with regard to jurisdictional claims in published maps and institutional affiliations.

Copyright: () 2020 by the authors. Licensee MDPI, Basel, Switzerland. This article is an open access article distributed under the terms and conditions of the Creative Commons Attribution (CC BY) license (https: / / creativecommons.org/ licenses/by/4.0/).

\begin{abstract}
Over the last decades, microalgal biomass has gained a significant role in the development of different high-end (nutraceuticals, colorants, food supplements, and pharmaceuticals) and lowend products (biodiesel, bioethanol, and biogas) due to its rapid growth and high carbon-fixing efficiency. Therefore, microalgae are considered a useful and sustainable resource to attain energy security while reducing our current reliance on fossil fuels. From the technologies available for obtaining biofuels using microalgae biomass, thermochemical processes (pyrolysis, Hydrothermal Liquefaction (HTL), gasification) have proven to be processed with higher viability, because they use all biomass. However, due to the complex structure of the biomass (lipids, carbohydrates, and proteins), the obtained biofuels from direct thermochemical conversion have large amounts of heteroatoms (oxygen, nitrogen, and sulfur). As a solution, catalyst-based processes have emerged as a sustainable solution for the increase in biocrude production. This paper's objective is to present a comprehensive review of recent developments on the catalyst-mediated conversion of algal biomass. Special attention will be given to operating conditions, strains evaluated, and challenges for the optimal yield of algal-based biofuels through pyrolysis and HTL.
\end{abstract}

Keywords: microalgal biomass; thermochemical conversion; catalytic upgrading; liquid fuels; hydrothermal liquefaction; pyrolysis; gasification

\section{Introduction}

Fossil fuels have been a critical commodity for the economic and social development of the modern world. However, their consumption has inevitably increased the levels of anthropogenic carbon dioxide $\left(\mathrm{CO}_{2}\right)$ emissions to concentrations that exceed the earth's absorption capacity through the natural carbon cycle [1]. Biomass-based fuels (or biofuels) are considered as a substitute for traditional fossil fuels [2] for both developed and nondeveloped countries due to their abundance and distribution [3].

Over the last years, several biomass resources such as grass, wood, crops and residues, animal waste, municipal solid waste, and even aquatic plants have been studied to produce biofuels [4]. However, up to date, microalgae are considered one of the most attractive sources of renewable energy and raw materials; it diversifies the scope of different industries in the elaboration of food and feed, pharmaceuticals, pigments, colorants, bioplastics, and protein hydrolysates [5].

Microalgae and cyanobacteria are a diverse group of photosynthetic microorganisms that naturally grow in lakes, rivers, and oceans. Microalgae offer several advantages over plant-based biofuels such as (i) high growth rate, (ii) use of non-arable lands, (iii) can be grown in wastewater, (iv) high consumption of $\mathrm{CO}_{2}$, and (v) their production can be directed toward the synthesis of several compounds of commercial interest [6]. 
To obtain biomass with a high concentration of specific metabolites is one the cornerstones of microalgae biotechnology. Several authors have proved that specific culturing conditions such as nutrient concentration [7], photobioreactor configuration [8], environmental conditions (temperature and illuminance), agitation, and $\mathrm{pH}$ [9] directly influence the cellular composition, resulting in the final concentration and productivity of the strain, as well as the variation in the content of specific metabolites (lipids, carbohydrates, proteins, and other components) [10].

The transformation of algal biomass into biofuels is not new. Several studies have covered different areas on the strain selection, culture method, and transformation into biofuel, which is the critical link in the production chain toward obtaining sustainable biofuels from microalgae.

The algal biomass produced under specific conditions can be transformed into energy by applying thermochemical and biochemical methods. Biofuel such as Bio-oil, biochar, synthesis gas (syngas), and heat are obtained through thermochemical conversion. On the other side, biodiesel, biohydrogen, biomethane (or biogas), and bioethanol can be produced via the biochemical conversion of algal biomass [1]. Although different forms of cultivation and production have been developed in recent years, it is still necessary to find an effective and sustainable production mechanism to reach the full potential of microalgae-based biofuels, especially in large-scale industrial applications.

One possible solution to achieve the potential of algae as a feedstock for biofuels is the use of reactions that employ whole biomass such as anaerobic digestion (AD) and thermochemical conversion. Biogas is the main product of $\mathrm{AD}$ and is considered one of the most promising biofuels that can address rising concerns about fossil fuels [11]. Another alternative is the application of catalytic-based processes such as Hydrothermal Liquefaction (HTL) and pyrolysis. Through thermochemical conversion, the biomass is decomposed under oxygen/air deficient conditions to produce Bio-oil, Biochar (specially on HTL and pyrolysis process), and syngas (especially on gasification process), which primarily consists of carbon monoxide $(\mathrm{CO})$ and carbon dioxide $\left(\mathrm{CO}_{2}\right)$ [12], the quantity and quality of the final product depends upon the process, reaction temperature, heating rate, and oxygen supply [13]. In comparison to the biochemical conversion of algal biomass, the thermochemical approach is a more straightforward route to produce biofuels due to several factors: (i) the entire biomass is employed as feedstock, (ii) the process times is shorter, and (iii) the final yield can be improved by the addition of chemical catalyst [14]. The present study is intended to give a comprehensive overview of the state-of-the-art usage of catalysts on the thermochemical conversion of algal biomass into solids, liquids, and gas biofuels. Special attention will be given to operating conditions, strains evaluated, and challenges for the optimal yield of algal-based biofuels through pyrolysis and HTL.

\section{Algae-Based Biofuels}

Biofuels are broadly classified by generations. First-generation (1st gen) biofuels are produced from food feedstock (corn, sugarcane, soybean, potato, beet, soybeans, coconut, sunflower, rapeseed, palm oil, switchgrass, Jatropha, Camelina, Cassava). Although 1st gen is considered a sustainable source of energy due to the reduction on greenhouse gas (GHG) emissions, specific details such as their competition with food supply, high requirement of government subsidies, large amounts of non-sustainable fertilizers, and environmental concerns due to the loss of biodiversity linked to the promotion of deforestation for large monoculture areas [15] hinder their true impact as a cleaner and more sustainable option over fossil fuels.

Second-generation (2nd gen) was conceived as a partial solution of several drawbacks of 1st gen biofuels. This generation relies on nonfood items such as cellulosic biomass, straw, manure, used cooking oil, and other non-conventional sources, which usually finish in landfills once their useful portion has been removed [12]. However, 2nd gen is still not industrially profitable due to biomass complexity and problems associated with its production, storage, and transportation [2]. 
Third-generation (3rd gen) focuses on the upgrade of aquatic feedstock, such as microalgal and cyanobacterial biomass, into different fuels. Microalgae have been praised as a better solution for the energy problem due to specific qualities of algal production: (i) do not compete with human and animal food stock, (ii) harvesting can be done through the year, (iii) can employ saline and wastewater, (iv) have better growth rate than higher plants, (v) can convert up to $183 \mathrm{G}$ tons of $\mathrm{CO}_{2}$ to produce $100 \mathrm{G}$ tons of biomass in comparison to higher plants such as wood crops (165 $\mathrm{G}$ tons of $\mathrm{CO}_{2}$ to produce $100 \mathrm{G}$ tons of biomass) [16], and (vi) the concentration of transformable metabolites (lipids and carbohydrates) is stable in the biomass. First, the selected strain had to be cultured until it reaches the largest possible biomass concentration in the photobioreactor; once reached, the biomass is removed from the culture media (centrifugation, flocculation, filtration, and other techniques) and dried. Then, the dried biomass is ready to be used as feedstock for several biofuels (biodiesel, bioethanol, biogas, and so on). These different sections have been the main topic of research over the last 20 years, attracting the attention of different universities, research centers, and energy companies worldwide such as Ecopetrol (Colombia), Exxon Mobile, Shell (US), Petrobras (Brazil), and Total (France).

\subsection{How the Production of Algae-Based Biofuels Changed over Time}

Several companies worldwide such as Solix biofuels, Corbion (previously known as Terravia or Solazyme), Cellana, Sapphire Energy, Seambiotic, Oil Fox, Synthetic genomics, Euglena, and others started the race for algae-based biofuels. However, after years of research, none of the companies proved the economic balance of algal-based biofuels [2]. The latter can be due to several problems identified through the last decade. First, the microalgal biodiversity is so vast that after ten years of research, we are still far from identifying the total diversity of algae and cyanobacteria [15]. Another problem related to the strains is the stability of their growth on industrial photobioreactors and the synthesis of the target metabolite [5,6].

Limited studies reported that few species of microalgae and cyanobacteria possess an inherent capacity for lipid synthesis and storage (Table 1).

Table 1. Different strains studied for biodiesel production.

\begin{tabular}{ccccc}
\hline Strain & $\begin{array}{c}\text { Lipids } \\
\mathbf{( w t} \% \mathbf{)}\end{array}$ & $\begin{array}{c}\text { Carbohydrates } \\
\mathbf{( w t \% )}\end{array}$ & $\begin{array}{c}\text { Proteins } \\
\mathbf{( w t \% )}\end{array}$ & Reference \\
\hline Arthrospira platensis & 30.23 & 31.89 & 16.81 & {$[17]$} \\
Auxenochlorella protothecoides & 42 & 26 & 30 & {$[18]$} \\
Botryococcus braunii & 45 & 10 & 44 & {$[19]$} \\
Chlamydomonas reinhardtii & 60 & 20 & 18 & {$[20]$} \\
Ch. reinhardtii CC-400 & 22.11 & 52.2 & 23.69 & {$[21]$} \\
Ch. Reinhardtii CC-4349 & 28.5 & $\mathrm{n} / \mathrm{a}$ & $\mathrm{n} / \mathrm{a}$ & {$[22]$} \\
Chlorella sp G-9 & 64.25 & $\mathrm{n} / \mathrm{a}$ & $\mathrm{n} / \mathrm{a}$ & {$[23]$} \\
C. kessleri & 36.5 & $\mathrm{n} / \mathrm{a}$ & $\mathrm{n} / \mathrm{a}$ & {$[24]$} \\
C. pyrenoidosa & 20 & 18.7 & 53.8 & {$[25]$} \\
C. vulgaris UTEX 259 & 19.8 & 14.8 & 57.3 & {$[26]$} \\
C. vulgaris UTEX 1803 & 28 & 35 & 20 & {$[27]$} \\
C. vulgaris Mutant (UV715) & 12 & 36 & 41 & {$[28]$} \\
Chlorococcum oleofaciens & 41 & $\mathrm{n} / \mathrm{a}$ & $\mathrm{n} / \mathrm{a}$ & {$[29]$} \\
Dunaliella tertiolecta & 20 & 42 & 35 & {$[30]$} \\
Nannochloropsis gaditana & 15 & 10 & 56 & {$[31]$} \\
Pseudokirchneriella Subcapitata & 40 & $\mathrm{n} / \mathrm{a}$ & 24.1 & {$[32]$} \\
Phaeodactylum tricornutum & 55.7 & 20 & 30 & {$[30]$} \\
Scenedesmus almeriensis & 13.1 & 9 & 22 & {$[33]$} \\
& 32.5 & $\mathrm{n} / \mathrm{a}$ & 30 & {$[34]$} \\
S. obliquus & 24.9 & $\mathrm{n} / \mathrm{a}$ & $\mathrm{n} / \mathrm{a}$ & {$[35]$} \\
& 35 & $\mathrm{n} / \mathrm{a}$ & $\mathrm{n} / \mathrm{a}$ & {$[36]$} \\
Tetraselmis suecica & 9.03 & 22 & 32 & {$[37,38]$} \\
& 25.07 & 17.52 & 37.27 & {$[39]$} \\
\end{tabular}


Initially, the studies focused on applying industrially relevant strains such as Spirulina (Arthorspira) [17], Auxenochlorella [18], Botryococcus [19,20], Chlamydomonas [21-23], Chlorella [24-29], Dunaliella [34], Scenedesmus [38-43], and Tetraselmis [44,45]. Over time, other strain with a unique capacity for the synthesis of lipids and hydrocarbons such as Botryococcus braunii $[19,20]$ were isolated and identified, and more recently, the scientific community has opted for the production of mutant strains with large lipid storage [22,23,31].

Microalgae can be produced under autotrophic, mixotrophic, or heterotrophic conditions. Different systems for the production of algae are available for their culture under the three conditions, as mentioned earlier [41]. Autotrophic systems are the most common, since the algae only require light as an energy source and dissolved $\mathrm{CO}_{2}$ as a source of carbon. Usually, algae growth under autotrophic systems can be produced in open or closed photobioreactors. Open ponds are the simplest of all systems for algal production, and it requires low energy inputs. It has easy maintenance; however, it is severely affected by seasonal variations and is prone to contamination by other microbes [42]. Mixotrophic and heterotrophic production of algae requires the addition of organic carbon sources (glucose, acetate, and others), which can lead to contamination by the presence of bacteria and fungi; therefore, these systems require closed photobioreactors (PBR). Closed PBR offers several advantages over open systems: (i) aseptic growth conditions, (ii) increased cell concentration due to better light distribution, (iii) improved $\mathrm{pH}$ control, and (iv) reduced water loss due to evaporation. However, their operation cost, maintenance, and energy inputs are considerably higher than in open ponds [42].

After biomass production, the cells are harvested from the media. Due to their nature, microalgal cells have a small size and low specific gravity; therefore, their concentration and harvesting are energy and time-intensive [43]. Several techniques are available at industrial scale such as centrifugation, filtration, flocculation, flotation, electroflotation, and so on [10]. However, the method's selection and application lie on the technical and economic analysis since some of them can be extremely expensive and energy-intensive for the production of algal-based biofuels [44]. Once the biomass is removed from the media, most of the cell water content must be removed via spray drying, drum drying, freezedrying, or solar drying to avoid any interference with the extraction [41]. Following drying comes the extraction of lipids and carbohydrates, which is considered as the crucial step that inhibits the industrial-scale production of algae-based biofuels [44]. The microalgal cell wall is made of polysaccharides and cellulose synthesized from silicic acid [45], and it must be broken in order to release both lipids and carbohydrates; as a consequence, only a fraction of the biomass is used in biofuel process production. Therefore, biodiesel and bioethanol production are still not economically feasible due to the high cost and energy inputs in almost all stages [46]. Other biofuels such as biogas and biohydrogen have gained attention as sustainable alternatives for energy production using microalgal biomass.

\subsection{Biochemical Conversion for Third-Generation Biofuel}

The biochemical conversion of algal biomass into third-generation biofuels are divided into biodiesel, bioethanol, biogas, and biohydrogen. Biodiesel from algae requires the extraction and conversion of lipidic fraction into low atomic weight compounds, biodegradable fatty acid methyl esters (FAME), for hands ready usage in engines through transesterification [47]. In the transesterification reaction in the presence of a chemical (acid, alkali) or biological (lipase) catalyst [48], methanol or ethanol is used to increase the reaction rate and maintain a balance change toward the production of fatty acid esters with glycerol as a by-product [49]. The biodiesel derived from algal biomass has a petrodiesellike calorific value (39-41 MJ $/ \mathrm{kg}$ ) [50]; it also has a higher percentage of unsaturated fatty acid compared to saturated fatty acid, which is a prerequisite for fuel engineering [51]. A higher degree of unsaturation leads to better cold flow; however, insoluble particle production is simultaneously increased [52]. 
Microalgae are an alternative resource for bioethanol production as they showed higher productivity than certain feedstocks for bioethanol production, such as sugarcane and corn [53]. Several strains accumulate carbohydrates in excess (mainly as insoluble starch and cellulose, with the absence of lignin) of up to $50 \%$ of their dry weight (DW) [54]. These carbohydrates are not readily fermentable to bioethanol [55]; thus, pretreatment processes, including chemical (acid and alkaline) or enzymatic hydrolysis, are crucial [56-58].

There are many pretreatment methods (acid, basic, and enzymatic hydrolysis); however, their cost can significantly contribute up to $30 \%$ of the total cost of bioethanol production [59]. Acid hydrolysis is quicker and cheaper under high temperatures and pressures but can decompose sugar into inhibitors [60-62]. Conversely, under mild temperatures and pressure, enzymatic hydrolysis can be achieved, but it is slower, more costly, and still involves physical or chemical pretreatment [63].

Biogas is produced via a sequence of biochemical processes converting the organic material: hydrolysis, fermentation, acetogenesis, and methanogenesis, also known as anaerobic digestion (AD) [64]. In this process, the whole biomass is used for the production of methane (55-75\%) and carbon dioxide (25-45\%) [65]; therefore, the energy performance is higher in comparison to biodiesel and bioethanol [66]. Additionally, nutrients such as organic nitrogen or phosphorus may be mineralized and subsequently recycled for algae cultivation [67]. Unlike biogas, biohydrogen is produced via their metabolic pathways along with the cell growth; therefore, it does not require further processing of the biomass (i.e., harvesting, dewatering, drying, and extraction), and it is considered clean and renewable, with higher energy production $(142 \mathrm{MJ} / \mathrm{Kg})$ [68]. Biohydrogen can be obtained by photofermentation, dark fermentation, direct and indirect biophotolysis [69]; however, hydrogen production cannot be achieved amidst effective photosynthesis, as oxygen inactivates hydrogenase [70]. The Research and Development on algal-based biofuels is a field that, in recent years, has been maintained with a considerable number of publications. Figure 1 shows the number of publications per year in the last 18 years, according to the Scopus database (Elsevier). It is possible to observe an exponential increase in the number of publications between 2006 and 2015. Since 2016, the number of documents has remained almost constant up to a final number of 8022 (including accepted manuscripts for 2021). The United States, China, India, South Korea, and the United Kingdom dominate the scientific publication on algal-based biofuels.

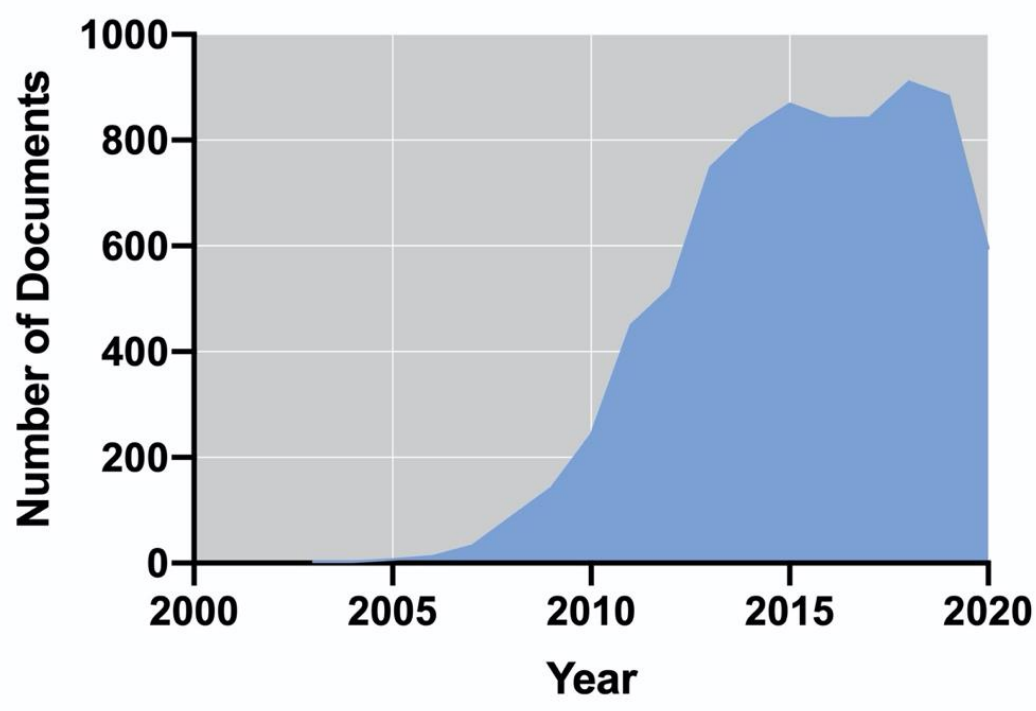

(a)

Figure 1. Cont. 


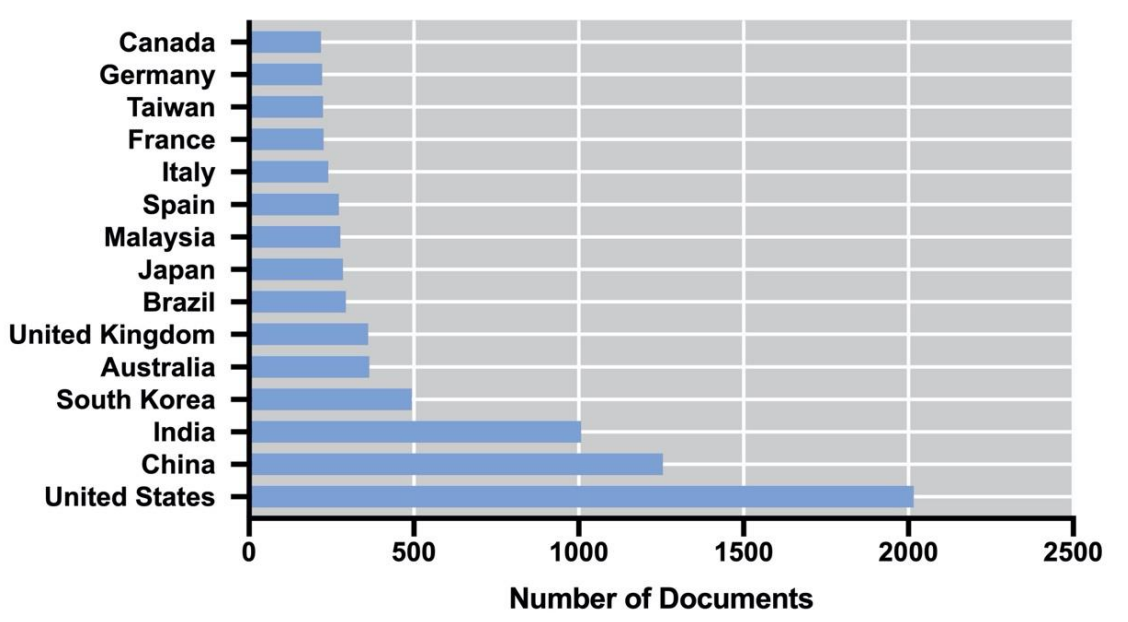

(b)

Figure 1. Evolution of the number of publications from 2003 to 2020 on algal biofuels (a) and their country of origin (b).

\section{Thermochemical Conversion of Algal Biomass}

Thermochemical methods can be grouped into four classes (Figure 2): hydrothermal liquefaction, pyrolysis, gasification, and torrefaction [71]. In the thermochemical process, the algal biomass is thermally decomposed into usable biofuels such as syngas, bio-oil, and biochar (Figure 2). Unlike the biochemical production of biofuels, thermochemical processes do not require the extraction of lipids nor carbohydrates; therefore, the entire biomass can be used. Finally, the reaction time is short, providing a simpler route for the biofuel production [10].

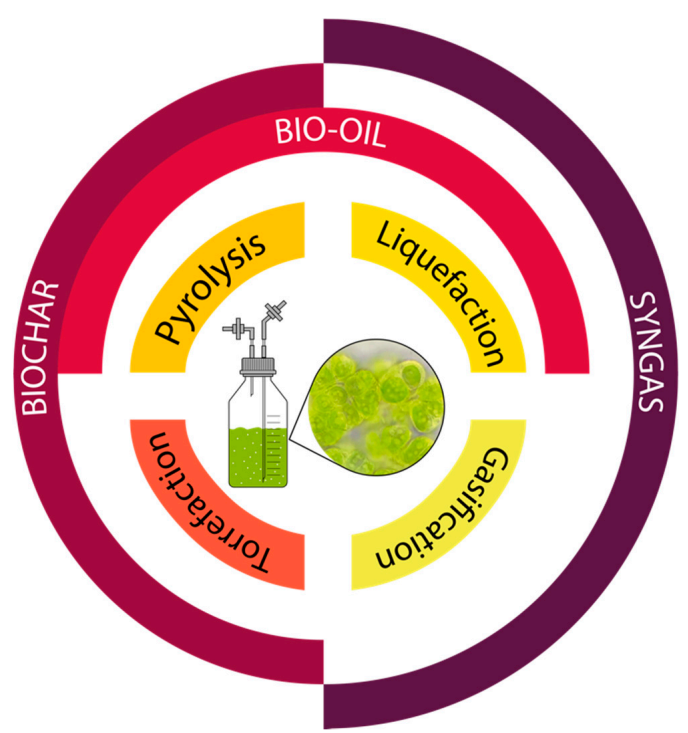

Figure 2. Different thermochemical conversion methods of microalgal biomass and their main products.

\subsection{Microalgal Torrefaction}

Torrefaction (usually called mild pyrolysis) is a pretreatment process focused on altering the physicochemical properties of biomass to improve their fuel characteristics and applicability in thermal conversion processes [72]. Their application of microalgae is relatively new (Figure 3a), with the first reported use in 2011. Usually, the reaction temperature of the torrefaction process occurs between 200 and $300{ }^{\circ} \mathrm{C}$, under slow heating rates $\left(<50{ }^{\circ} \mathrm{C} / \mathrm{min}\right)$, mainly in an inert environment $[73,74]$. The torrefied biomass poses several 
advantages: higher heating value, lower atomic $\mathrm{O} / \mathrm{C}$ and $\mathrm{H} / \mathrm{C}$ ratios, lower moisture content, higher water-resistivity, and improved reactivity [72]. There are several reports of torrefaction (both wet and dry) on algal biomass upgrade. The torrefied biomass of S. platensis $\left(300{ }^{\circ} \mathrm{C}\right.$ and $30 \mathrm{~min}$ ) showed an increase in the higher heating value (from 20 to $25.92 \mathrm{MJ} / \mathrm{kg}$ ) and a lower moisture content (from 7.61 to $1 \mathrm{wt} \%$ ) in comparison to untreated biomass [73]. In a different study, $C$. vulgaris ESP-31 was torrefied in the presence of water ( $20 \mathrm{~g}$ dried microalga and $100 \mathrm{~g}$ of distilled water) using different temperatures $\left(160,170\right.$, and $\left.180^{\circ} \mathrm{C}\right)$ for $10 \mathrm{~min}$. The torrefied biomass showed an increased fixed carbon (25.29 and $16.39 \mathrm{wt} \%$ respectively) and Higher Heating Value (HHV) in comparison with raw biomass (24.49 and $22.02 \mathrm{MJ} / \mathrm{kg}$, respectively) [75]. In a complementary study, the treated biomass of $C$. vulgaris ESP-31 was further transformed through gasification [76]. As a result, the biomass reached the devolatilization peak at lower temperatures (between 266 and $\left.270{ }^{\circ} \mathrm{C}\right)$ compared to raw samples $\left(287.7^{\circ} \mathrm{C}\right)$. The efficiency of torrefaction is linked to temperature and time reaction [77]. According to Chen et al. [78], $300{ }^{\circ} \mathrm{C}$ and $30 \mathrm{~min}$ increased the final HHV content in Chlamydomonas sp. JSC4 (from 19.27 to $25 \mathrm{MJ} / \mathrm{kg}$ ). Another possibility is the application of wet torrefaction for the co-production of biochar and bioethanol; Yu et al. $[79,80]$ torrefied C. vulgaris ESP-31 biomass addition of $0.2 \mathrm{M}$ $\mathrm{H}_{2} \mathrm{SO}_{4}\left(170{ }^{\circ} \mathrm{C}, 10 \mathrm{~min}\right)$. Their results show a significant increase in the HHV, from 19.23 to $32.35 \mathrm{MJ} / \mathrm{kg}$, while the hydrolysate contained a considerably high content of total reducing sugar $(7.31-98.11 \mathrm{~g} / \mathrm{L})$.

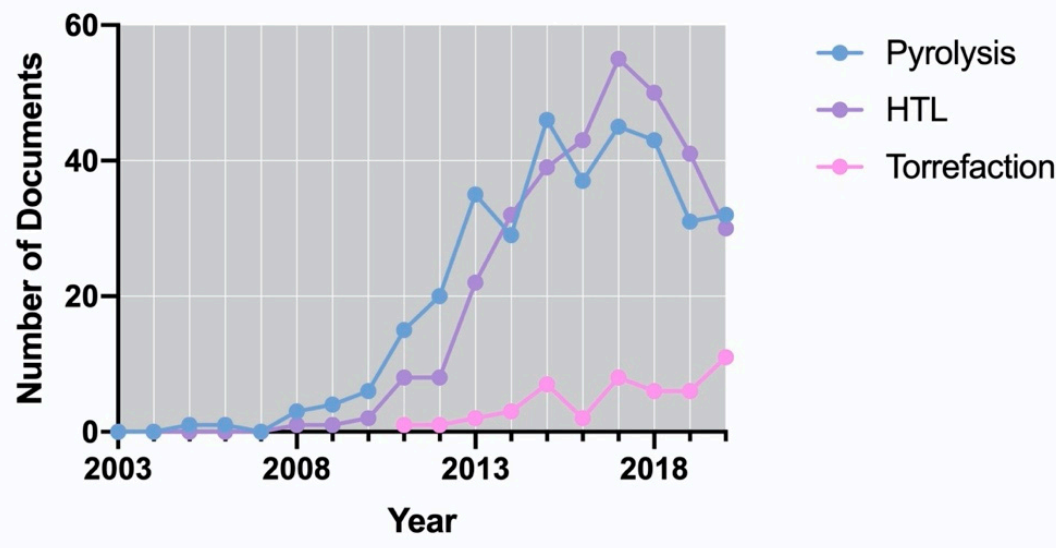

(a)

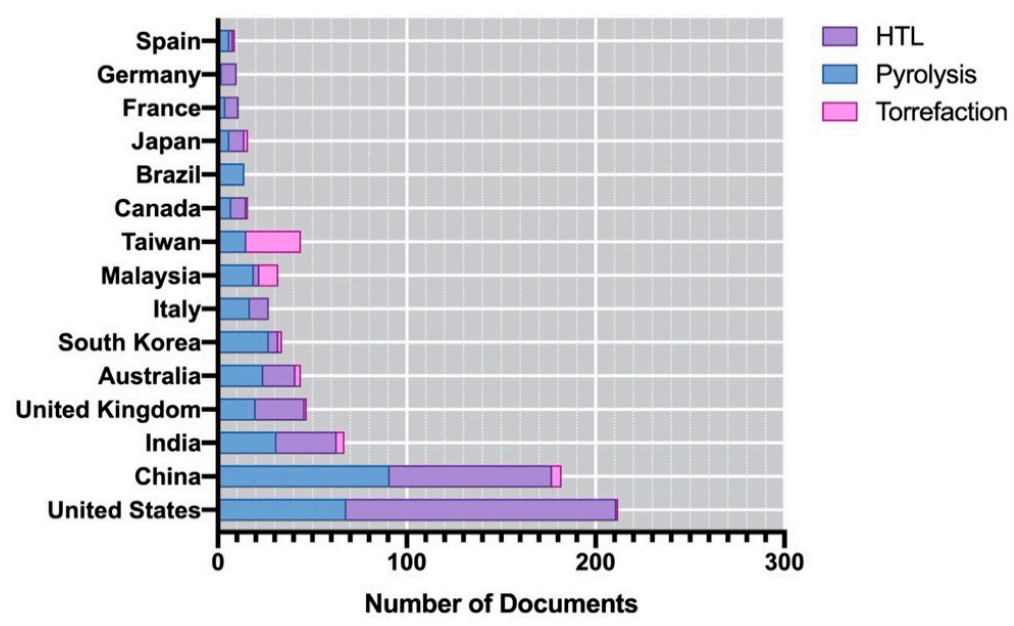

(b)

Figure 3. Evolution of the number of publications from 2003 to 2020 on torrefaction, pyrolysis and Hydrothermal Liquefaction (HTL) using algal biomass (a) and their country of origin (b). 


\subsection{Pyrolysis of Microalgae}

Pyrolysis is the thermal decomposition of biomass at high temperature $\left(400-600{ }^{\circ} \mathrm{C}\right)$, in an atmospheric-pressure inert environment. Compared to other conversion technologies, the pyrolysis of algal biomass has achieved reliable and promising outcomes that could lead to commercial exploitation [81]. Due to the lipid and protein content of algal biomass, the biooils obtained have a higher heating value (10-35 MJ $/ \mathrm{kg}$ ) [82], higher aromatics, and lower acidity ( $\mathrm{pH}$ 3.7) compared to lignocellulosic biomass (15.14-30.47 MJ $/ \mathrm{kg}, \mathrm{pH}<3$ ) [83-85].

Pyrolysis can be categorized in five modes: (i) slow, (ii) intermediate (iii) fast, (iv) flash, and (v) microwave pyrolysis; each one possesses a differential heating rate, the presence, and/or heating route [9]. Slow pyrolysis is characterized by the heating of biomass under a "slow" heating rate $\left(0.1-0.8^{\circ} \mathrm{C} / \mathrm{s}\right)$, with moderate temperature $\left(300-500{ }^{\circ} \mathrm{C}\right)$ and long retention times (5-60 $\mathrm{min}$ ) [86-88]. Their main product is biochar with byproducts such as bio-oil and syngas [89]. Under slow pyrolysis, different particle sizes can be processed; therefore, both macro and microalgae can be used without mechanical pretreatment. Intermediate pyrolysis is carried out using the intermediate conditions between slow and fast pyrolysis [90]. Normally, intermediate pyrolysis occurs at moderate temperatures of reaction (up to $500^{\circ} \mathrm{C}$ ), $0.5-25$ min residence times for feedstocks, and 2-4 s moderate residence times for vapor [91]. The main product from intermediate pyrolysis is bio-oil (40-60\%) followed by non-condensable syngas (20-30\%) and biochar (15-25\%) [92], the bio-oil obtained has a reduced viscosity with a small concentration of $\operatorname{tar}$ [93], and the syngas is mainly composed of hydrogen $\left(\mathrm{H}_{2}\right)$, carbon monoxide $(\mathrm{CO})$, carbon dioxide $\left(\mathrm{CO}_{2}\right)$ and methane $\left(\mathrm{CH}_{4}\right)$ [94]. Both bio-oil and syngas can be further refined into fuels for energy, heat, and transport [95]. One interesting product from intermediate pyrolysis is hydrogen. Generally, $\mathrm{H}_{2}$ is not expected in conventional pyrolysis gas, as no reduction process for $\mathrm{H}_{2}$ formation occurs; however, the contact between hot char and water vapor lead to $\mathrm{CO}$ and $\mathrm{H}_{2}$ [96].

Biochar is a carbon-rich charcoal material that can be obtained from any biomass feedstock by thermal decomposition under minimal oxygen $\left(\mathrm{O}_{2}\right)$ supply [97] and contains most of the feedstock mineral components [98]. As mentioned above, slow pyrolysis is the preferred method for biochar production. Biochar has a high heat value, carbon content, porosity, and strong capacity reduction [99]. Due to its sustainable nature and its carbonneutral properties [100], biochar is mainly focused on carbon reduction, soil amendment, energy resources, and water treatment [101], More recently, several researchers used biochar to synthesize metal-supported catalysts due to their unique physical properties and low price [102]. In a study on the slow pyrolysis of six genera of macroalgae, the authors obtained high yields of biochar (45.3-62.4 wt\%) with moderate HHV values (10.7-17.8 MJ $/ \mathrm{kg}$ ) [84]. On another study, Chlorella sp. produced higher biochar yield (41 wt $\%)$ with relatively high heating value $(21.5 \mathrm{MJ} / \mathrm{kg}$ ) in comparison of the macroalga Sargassum sp. (39 wt\% and $18.5 \mathrm{MJ} / \mathrm{kg}$ ) [99]. Temperature is an important parameter on biochar production; when biomass from Laminaria japonica was subjected to higher temperatures under slow pyrolysis $\left(600^{\circ} \mathrm{C}\right)$ the yield of biochar was reduced from 78.34 to $27.05 \%$, while ash content increased from 22.92 to $64.19 \%$ [103]. Finally, unlike most studies, Wang et al. [98] obtained a higher biochar yield (31 wt \%) under fast pyrolysis of $C$. vulgaris; however, this result can be due an unusually high ash content on the biomass.

The preferred method for optimizing bio-oil production is fast pyrolysis; this method is carried out at elevated temperatures $\left(850-1100^{\circ} \mathrm{C}\right)$, fast heating rate $\left(>1^{\circ} \mathrm{C} / \mathrm{s}\right)$, and short pyrolysis time $(0.5-10 \mathrm{~s})[104,105]$. These conditions reduce secondary reactions (secondary cracking, condensation, and polymerization of intermediates), which contribute to the production of high bio-oil yields, making it efficient for biomass conversion $[83,106]$. Flash pyrolysis uses high temperatures $\left(950-1250{ }^{\circ} \mathrm{C}\right)$, high heating rates $\left(>1000{ }^{\circ} \mathrm{C} / \mathrm{s}\right)$, and a reduced time $(0.5-10 \mathrm{~s})$, with bio-oil as their main product $(90 \mathrm{wt} \%)[89,107]$. Finally, Microwave-Assisted Pyrolysis (MAP) employs a heating rate between conventional pyrolysis and fast pyrolysis [107]. It is considered a more energy-efficient method than other pyrolysis-related systems [108], since it can use different particle size biomass. Over the last 
years, several studies have been conducted to increase the efficiency of pyrolysis process using microalgal genera such as Arthrospira sp. [109], Chaetocerous sp. [93], Chlamydomonas sp. [4,110], Chlorella sp. [83,111-115], Desmodesmus sp. [116], Dunaliella sp. [93], Haematococcus sp. [93,117], Isochrysis sp. [118-120], Microcystis sp. [105], Nannochloropsis sp. [121-124], Oscillatoria sp. [125], Pavlova sp. [126,127], Schizochytrium sp. [128], Tetraselmis sp. [118,119], Spirulina sp. [112,129,130], and Synechococcus [119]. A detailed list of species studied can be found in Table 2.

The application of catalyst on microalgal pyrolysis is an alternative to increase selectivity for certain pyrolytic products (liquid, solid or gas) and improve process parameters (reduced temperature and processing time) [98]; it can also lead to in situ upgrading of generated bio-oil with less oxygenic compounds, which prevent polymerization and condensation [83,131]. Another advantage is that catalysts used for pyrolysis can be recycled to the reactor [83]. Various catalysts such as acid type, base type, metal type, zeolite type, carbon type or a combination of different materials may be used to improve pyrolysis [98]. The most common catalysts used include $\mathrm{Na}_{2} \mathrm{CO}_{3}$, metallic-based catalysts such as $\mathrm{Ni}, \mathrm{Mo}$, and ceria-based catalysts $\left(\mathrm{NieCe} / \mathrm{Al}_{2} \mathrm{O}_{3}\right.$ and $\mathrm{NieCe} / \mathrm{ZrO}_{2}$ ) have shown great catalytic efficiency [126]. On the other hand, other metal catalysts including $\mathrm{Ce}, \mathrm{Ti}$, $\mathrm{Co}, \mathrm{Mg}$, and $\mathrm{Al}$ did not show obvious catalytic effect [107]. ZSM-5-based zeolites such as H-ZSM-5, Fe-ZSM-5 Cu-ZSM-5, Ni-ZSM-5, and Ga-HZSM-5 are considered as the most effective catalyst for the pyrolysis of algal biomass. Ga-ZSM-5 is called a bifunctional catalyst, where Ga promotes decarbonylation and olefin aromatization reactions, while the remaining reactions (e.g., oligomerization and cracking) are catalyzed by the ZSM-5 [132]. In the study on the catalytic pyrolysis of C. vulgaris with egg whites, Ga-HZSM-5 and Cu-ZSM-5 increased the Aromatic production from $16.72 \%$ for normal HZSM-5 (30) to $21.16 \%$ and $18.03 \%$, respectively [133]. Another study [132] found that Ga/ZSM-5 catalysts increased the yield of aromatics using Catalytic fast pyrolysis (CFP) by $40 \%$ compared to ZSM-5 catalyst. In the catalytic pyrolysis of Jatropha residues, [134] found that Ga/HZSM-5 yield the highest aromatics (95\%) high monocyclic aromatic hydrocarbons (MAHs) and low polycyclic aromatic hydrocarbons (PAHs) selectivity of $87 \%$ and $13 \%$, respectively. Other zeolites such as ITQ-2 and MCM-22 had a similar but less effective function [135]. In a study on the catalytic pyrolysis of Nannochloropsis sp. [121] were able to significantly reduce the oxygen content (from 30 to $19 \mathrm{wt} \%$ ) and a higher calorific value (from 24.6 to $32.5 \mathrm{MJkg}$ ). Other studies such as [136-138] proved the ability of catalytic-mediated pyrolysis to increase the yield of bio-oil.

Du et al. [137] found that an increase in catalyst-to-biomass ratio from 1:1 to 5:1 using HZSM-5 significantly improved the aromatic yields. On the other hand, Gao et al. [138] obtained bio-oil with less nitrogenated compounds through the usage of $\mathrm{Mg}-\mathrm{Al}$ layered double oxide/ZSM-5 composites on the pyrolysis of cyanobacterial biomass. On another study, Aysu et al. [118] improved the yield and quality of bio-oil from Tetraselmis sp. and Isochrysis sp. in a fixed bed reactor with the addition of $\mathrm{NieCe} / \mathrm{Al}_{2} \mathrm{O}_{3}$ and $\mathrm{NieCe} / \mathrm{ZrO}_{2}$. Campanella et al. [111] investigated the efficiency of five different zeolite-based catalysts (H-, Fe-, Cu-, and Ni-ZSM-5) in the bio-oil production from Chlorella biomass, and they found that HZSM-5 increased the yield of the hydrocarbon fraction in the organic phase from 21 to $43 \mathrm{wt} \%$. Finally, Mo et al. [129] evaluated the efficiency of MgO and ZSM-5 under environment enriched with $\mathrm{N}_{2}$ and $\mathrm{CO}_{2}$, where maximum bio-oil (46.2 wt \%) was obtained with basic metal $\mathrm{MgO}$. Figure 3 shows the evolution of the number of publications per year along the last 16-year period. According to the data obtained from the Scopus database (Elsevier), it is possible to observe an exponential increase in the number of publications between 2008 and 2017. Finally, the United States, China, India, South Korea, and the United Kingdom dominate the scientific publication on the application of torrefaction, pyrolysis, and HTL. 
Table 2. Strains studied on catalytic pyrolysis and their catalyst.

\begin{tabular}{|c|c|c|c|c|c|c|c|c|c|}
\hline Strain & HHV (MJ/kg) & $\begin{array}{c}\text { Heating Rate } \\
\left({ }^{\circ} \mathrm{C} / \mathrm{min}\right)\end{array}$ & $\begin{array}{l}\text { Pyrolysis Time } \\
\text { (min) }\end{array}$ & $\begin{array}{c}\text { Pyrolysis } \\
\text { Temperature } \\
\left({ }^{\circ} \mathrm{C}\right)\end{array}$ & Catalyst & $\begin{array}{c}\text { Bio-oil } \\
\text { (wt\%) }\end{array}$ & $\begin{array}{c}\text { Bio-char } \\
(w t \%)\end{array}$ & $\begin{array}{c}\text { Syngas } \\
\text { (wt\%) }\end{array}$ & Reference \\
\hline \multirow{3}{*}{ Arthrospira plantensis } & \multirow{3}{*}{21.45} & \multirow{3}{*}{100} & \multirow{3}{*}{30} & \multirow{3}{*}{$400-700$} & Ni/HMS-ZSM5 & 32.52 & 34.04 & 33.44 & \multirow{3}{*}{ [109] } \\
\hline & & & & & Fe/HMS-ZSM5 & 30.01 & 31.84 & 38.15 & \\
\hline & & & & & Ce/HMS-ZSM5 & 31.80 & 31.79 & 36.41 & \\
\hline Chlamydomonas reinhardtii & 20.47 & 150 & $10-34$ & 500 & hydrotalcite & 54.84 & 37.59 & 7.57 & {$[110]$} \\
\hline \multirow{2}{*}{ Ch. debaryana } & \multirow{2}{*}{21.9} & \multirow{2}{*}{$>200$} & \multirow[b]{2}{*}{30} & \multirow{2}{*}{$500-800$} & $\beta$-zeolite & 23.5 & $\mathrm{n} / \mathrm{a}$ & $\mathrm{n} / \mathrm{a}$ & \multirow{2}{*}{ [4] } \\
\hline & & & & & Activated charcoal & 43.8 & $\mathrm{n} / \mathrm{a}$ & $\mathrm{n} / \mathrm{a}$ & \\
\hline \multirow{5}{*}{ Chlorella sp. } & 21.2 & $\mathrm{n} / \mathrm{a}$ & 30 & $300-450$ & Fe-ZSM-5 & 43.1 & 29.7 & 27.1 & {$[83]$} \\
\hline & \multirow[t]{2}{*}{19.5} & \multirow[t]{2}{*}{$\mathrm{n} / \mathrm{a}$} & \multirow[t]{2}{*}{10} & \multirow[t]{2}{*}{500} & Cu-ZSM-5 & 46.9 & 27.9 & 24.6 & \multirow[t]{2}{*}{ [111] } \\
\hline & & & & & Ni-ZSM-5 & 45.1 & 30.1 & 25.4 & \\
\hline & \multirow[b]{2}{*}{$\mathrm{n} / \mathrm{a}$} & \multirow[b]{2}{*}{$\mathrm{n} / \mathrm{a}$} & \multirow[b]{2}{*}{50} & \multirow[b]{2}{*}{$350-650$} & Magnetite & 53.8 & 27.4 & 22.8 & \multirow[b]{2}{*}{ [112] } \\
\hline & & & & & Activated carbon & 49.4 & 37.3 & 13.3 & \\
\hline & 16.8 & 10 & 30 & 700 & $\mathrm{H}^{+} \mathrm{ZSM}-5$ & 25 & 24 & $\mathrm{n} / \mathrm{a}$ & [113] \\
\hline C. vulgaris & $\mathrm{n} / \mathrm{a}$ & 10 & 30 & $300-600$ & Ni-ZSM-5 & 18.97 & $\mathrm{n} / \mathrm{a}$ & $\mathrm{n} / \mathrm{a}$ & [114] \\
\hline & 18.6 & 48 & 30 & 500 & $\mathrm{H}^{+} \mathrm{ZSM}-5$ & 52.7 & 25.7 & 21.6 & [115] \\
\hline Desmodesmus communis & $\mathrm{n} / \mathrm{a}$ & $\mathrm{n} / \mathrm{a}$ & 20 & 460 & HZSM-5 & 8 & 42 & $\mathrm{n} / \mathrm{a}$ & [116] \\
\hline & & & & & $\mathrm{KOH}$ & 11 & 65 & 76 & \\
\hline & & & & & $\mathrm{K}_{2} \mathrm{CO}_{3}$ & 13 & 64.8 & 22.2 & \\
\hline Haematococcus pluvialis & 8.98 & 10 & $\mathrm{n} / \mathrm{a}$ & 600 & $\mathrm{MgO}$ & 12.5 & 62 & 25.5 & [117] \\
\hline & & & & & $\mathrm{Al}_{2} \mathrm{O}_{3}$ & 15 & 61 & 24 & \\
\hline & & & & & $\mathrm{CaO}$ & 13 & 63 & 24 & \\
\hline & & & & & Microalgae Residue & 15 & 60 & 25 & \\
\hline & & & & & $\mathrm{CeO}_{3}$ & 23 & 30 & 47 & \\
\hline & & & & & $\mathrm{Ce} / \mathrm{Al}_{2} \mathrm{O}_{3}$ & 25 & 32 & 42 & \\
\hline & & & & & $\mathrm{NiCe} / \mathrm{Al}_{2} \mathrm{O}_{3}$ & 24 & 32 & 43 & \\
\hline & 12.38 & 100 & 60 & 500 & $\mathrm{MgCe} / \mathrm{Al}_{2} \mathrm{O}_{3}$ & 23 & 31 & 46 & [118] \\
\hline Isochrysis sp. & & & & & $\mathrm{Ce} / \mathrm{ZnO}_{2}$ & 25 & 29 & 54 & \\
\hline & & & & & $\mathrm{NiCe} / \mathrm{ZnO}_{2}$ & 23 & 27 & 50 & \\
\hline & & & & & $\mathrm{MgCe} / \mathrm{ZnO}_{2}$ & 23 & 28 & 49 & \\
\hline & 15 & 100 & 20 & 500 & & 29 & 35 & 36 & [119] \\
\hline & 15 & 100 & 20 & 500 & L1-LSX-zeolite & 42.5 & 33 & 24.5 & [120] \\
\hline
\end{tabular}


Table 2. Cont.

\begin{tabular}{|c|c|c|c|c|c|c|c|c|c|}
\hline Strain & HHV (MJ/kg) & $\begin{array}{l}\text { Heating Rate } \\
\left({ }^{\circ} \mathrm{C} / \mathrm{min}\right)\end{array}$ & $\begin{array}{l}\text { Pyrolysis Time } \\
\text { (min) }\end{array}$ & $\begin{array}{c}\text { Pyrolysis } \\
\text { Temperature } \\
\left({ }^{\circ} \mathrm{C}\right)\end{array}$ & Catalyst & $\begin{array}{c}\text { Bio-oil } \\
\text { (wt\%) }\end{array}$ & $\begin{array}{c}\text { Bio-char } \\
(w t \%)\end{array}$ & $\begin{array}{c}\text { Syngas } \\
(w t \%)\end{array}$ & Reference \\
\hline \multirow{2}{*}{ Nannochloropsis sp. } & $\mathrm{n} / \mathrm{a}$ & 10 & 120 & $300-500$ & HZSM-5 & 25 & 38 & $\mathrm{n} / \mathrm{a}$ & [121] \\
\hline & $\mathrm{n} / \mathrm{a}$ & $\mathrm{n} / \mathrm{a}$ & 15 & $500-900$ & HZSM-5 & 49 & 40 & 10 & [123] \\
\hline N. oculata & 18 & $\mathrm{n} / \mathrm{a}$ & $\mathrm{n} / \mathrm{a}$ & $400-600$ & $\mathrm{Co}-\mathrm{Mo} / \gamma-\mathrm{Al}_{2} \mathrm{O}_{3}$ & 26 & 42 & $\mathrm{n} / \mathrm{a}$ & [124] \\
\hline \multirow{4}{*}{ Oscillatoria sp. } & 14.26 & 20 & 120 & 550 & $\mathrm{TiO}_{2}, \mathrm{ZnO}$ & 33.33 & 43.05 & 26.25 & [125] \\
\hline & & & & & $\mathrm{CeO}_{3}$ & 21.07 & 47.96 & 45.92 & \\
\hline & 12.96 & 100 & 60 & $450-550$ & $\mathrm{Ce} / \mathrm{TiO}_{3}$ & 21.67 & 47.44 & 46.26 & [126] \\
\hline & & & & & $\mathrm{Ni} / \mathrm{TiO}_{3}$ & 22.55 & 47.66 & 45.39 & \\
\hline \multirow{6}{*}{ Pavlova sp. } & & & & & $\mathrm{Co} / \mathrm{TiO}_{3}$ & 20.4 & 48.28 & 44.61 & \\
\hline & & & & & $\mathrm{CeO}_{2}$ & 21.07 & 37.86 & 41.07 & \\
\hline & & & & & $\mathrm{TiO}_{2}$ & 20.04 & 39.49 & 40.47 & \\
\hline & 12.96 & 100 & 60 & $450-550$ & $\mathrm{Ce} / \mathrm{TiO}_{2}$ & 21.67 & 37.46 & 40.87 & [127] \\
\hline & & & & & $\mathrm{Ni} / \mathrm{TiO}_{2}$ & 22.55 & 37.16 & 40.29 & \\
\hline & & & & & $\mathrm{Co} / \mathrm{TiO}_{2}$ & 20.41 & 38.85 & 40.74 & \\
\hline \multirow[t]{4}{*}{ Schizochytrium limacinum } & 25.8 & $\mathrm{n} / \mathrm{a}$ & $\mathrm{n} / \mathrm{a}$ & $350-800$ & $\mathrm{ZYNa}$ & 26 & 9 & $\mathrm{n} / \mathrm{a}$ & [128] \\
\hline & & & & & $\mathrm{Ce} / \mathrm{Al}_{2} \mathrm{O}_{3}$ & 25 & 17 & 58 & \\
\hline & & & & & $\mathrm{NiCe} / \mathrm{Al}_{2} \mathrm{O}_{3}$ & 25 & 17 & 58 & \\
\hline & & & & & $\mathrm{MgCe} / \mathrm{Al}_{2} \mathrm{O}_{3}$ & 23 & 16 & 51 & \\
\hline \multirow{4}{*}{ Tetraselmis sp. } & 12.07 & 100 & 60 & 500 & $\mathrm{Mg} / \mathrm{ZnO}_{2}$ & 23 & 18 & 59 & [118] \\
\hline & & & & & $\mathrm{Ce} / \mathrm{ZnO}_{2}$ & 23 & 17 & 58 & \\
\hline & & & & & $\mathrm{NiCe} / \mathrm{ZnO}_{2}$ & 23 & 16 & 51 & \\
\hline & & & & & $\mathrm{MgCe} / \mathrm{ZnO}_{2}$ & 23 & 17 & 58 & \\
\hline \multirow{2}{*}{ Spirulina sp. } & & & & & Magnetite & 49.4 & 25.4 & 25.2 & [112] \\
\hline & $\mathrm{n} / \mathrm{a}$ & $\mathrm{n} / \mathrm{a}$ & 50 & $350-650$ & Activated carbon & 46.4 & 33.2 & 20.4 & [112] \\
\hline \multirow{3}{*}{ S. platensis } & & & & & ZSM-5 & 44.8 & 21.1 & 34.1 & [129] \\
\hline & 17.6 & 15 & 60 & $350-500$ & $\mathrm{MgO}$ & 46.2 & 29.5 & 24.3 & {$[129]$} \\
\hline & 18.6 & 10 & $\mathrm{n} / \mathrm{a}$ & 400 & $\mathrm{Ce}(\mathrm{II}) / \mathrm{HZSM}-5$ & 49.7 & 20 & 30.3 & [130] \\
\hline
\end{tabular}




\subsection{Hydrothermal Liquefaction of Algal Biomass}

One of the problems with algal biomass is the necessity to remove the high-water content prior to the production of biofuels. In this case, Hydrothermal Liquefaction (HTL) stands out as a promising technology for the thermochemical conversion of biomass into more useful liquid fuels [139]. Unlike pyrolysis, HTL can convert high-moisture biomass to biocrude in water medium and thus does not require preliminary drying processes [140]. HTL is performed in the presence of water under high pressure (5-25 $\mathrm{MPa})$ and subcritical water temperature $\left(280-370^{\circ} \mathrm{C}\right)$. Under these conditions, macromolecules found within algal biomass (including lipid, protein, and carbohydrate) undergoes depolymerization reactions (fragmentation, hydrolysis, dehydration, deoxygenation, aromatization, and repolymerization) [141] for the production of several products such as bio-oil, gas, solid residue, and aqueous phase by-products [142]. HTL is considered a more robust thermochemical technology, not only for the usage of wet biomass, but also due to their high biocrude yield (24-64 $\mathrm{wt} \%$ ) [143]; some essential nutrients ( $\mathrm{N}, \mathrm{P}, \mathrm{Mg}$, and $\mathrm{K}$ ) can be recycled for microalgal culture [144]. Additionally, up to $50 \%$ of oxygen can be removed, resulting in a biocrude with a Higher Heating Value (HHV) ranging from 30 to $40 \mathrm{MJ} / \mathrm{kg}[145,146]$. However, the algae-derived biocrude possesses some disadvantages such as a high-water content, high viscosity, and high heteroatom content, which impede its upgrade into usable fuels [143]. Several studies underline that the biomass load/ratio, reaction temperature, residence time, pressure, catalyst (including homogenous and heterogeneous catalyst), and reaction medium influence the yield, composition, and physicochemical properties of biocrude obtained under HTL [147]. The application of catalysts on HTL reaction is an interesting opportunity to improve the process in several aspects such as the yield and quality of biocrude [148,149], inhibition of side reactions, decrease of reaction temperature, and pressure reduce its viscosity and the processing time [150]. The catalysts employed can be separated into homogeneous (water soluble) and heterogeneous (non-water soluble) [139]; Table 3 presents a list of homogeneous and heterogeneous catalysts employed on the conversion of algal biomass into biofuels.

\subsubsection{Homogeneous Catalysis}

Homogeneous catalysts are water-soluble at room temperature. During the reaction, the formation of char/tar is inhibited while enhancing product yield by expediting the water-gas shift reaction [150]. The most common forms include alkali salts $\left(\mathrm{Na}_{2} \mathrm{CO}_{3}\right.$ and $\mathrm{KOH})$, mineral and organic acids $\left(\mathrm{CH}_{3} \mathrm{COOH}\right.$ and $\left.\mathrm{HCOOH}\right)$, and metallic cations $\left(\mathrm{Zn}^{2+}\right.$ and $\left.\mathrm{Co}^{3+}\right)[149,150]$. Over the last years, several studies have been conducted to test the efficiency of different homogeneous catalyst using micro and macroalgal genera such as Chlorella sp. [151-154], Cyanidioschyzon sp. [155], Dunaliella sp. [156], Enteromorpha sp. [157], Isochrysis sp. [158], Laminaria sp. [159], Microcystis sp. [160], Nannochloropsis sp. [151,158,161], Pavlova sp. [158], Porphyridium sp. [151], Spirulina sp. [152,162,163], Tetraselmis sp. [163], Ulva sp. [164]; and a unknown mixture of algal species [165]. A detailed list of species and the catalyst studied can be found in Table 3 . 
$\mathrm{Na}_{2} \mathrm{CO}_{3}$ is the most common catalyst employed, and they can enhance the production of BTEX (benzene, toluene, ethylbenzenes, and xylenes) and C5 to C18 aliphatic hydrocarbons, which are critical elements of gasoline and diesel fuels [139]. In their work, Ref. [158] observed that $\mathrm{Na}_{2} \mathrm{CO}_{3}$ enhanced the yield of bio-crude from Nannochloropsis sp. at $250{ }^{\circ} \mathrm{C}$. However, at higher temperatures $\left(300-350{ }^{\circ} \mathrm{C}\right)$, other species studied such as Pavlova and Isochrysis sp. have higher bio-oil yields (50-60\%). The difference between results can be explained by the difference on biomass composition, since Pavlova and Isochrysis sp. have high lipid and carbohydrate contents. These results are consistent with those reported by [151], who observed that algae with high carbohydrate content were efficiently liquefied. In other study, [163] found that $\mathrm{Na}_{2} \mathrm{CO}_{3}$ increased the bio-oil yield up to $52 \%$ (29\% higher than for the uncatalyzed process) on Spirulina platensis, and $\mathrm{Ca}_{3}\left(\mathrm{PO}_{4}\right)_{2}$ and $\mathrm{NiO}$ produced a negative effect on bio-oil yield. On the other hand, [153] found that $\mathrm{Na}_{2} \mathrm{CO}_{3}$ does not improved the formation of bio-oil on a strain of $C$. vulgaris. $\mathrm{KOH}$ has been reported as an interesting catalyst; according to [155], in the catalytic HTL of Cyanidioschyzon merolae, $\mathrm{KOH}$ can increase the bio-oil yield in the range of 5-10\% of bio-oil (from 16.9 to $22.7 \%$ ) than for the non-catalytic process under similar reaction conditions. The performance of alkali catalyst is significantly affected by the temperature of the process, irrespective of the species evaluated $[153,160]$. For example, the formation of aliphatic and cyclics are directly affected with an increment of temperature $\left(300^{\circ} \mathrm{C}\right)$; however, at higher temperatures, their concentrations declined due to subsequent cracking [139]. Apart from alkaline catalysts, both organic $\left(\mathrm{HCOOH}\right.$ and $\left.\mathrm{CH}_{3} \mathrm{COOH}\right)$ and inorganic acid $\left(\mathrm{H}_{2} \mathrm{SO}_{4}\right)$ catalysts have been used [153,166]. According to Zhuang et al. [167], a concentration of $6 \%$ of $\mathrm{H}_{2} \mathrm{SO}_{4}$ increased up to $70 \%$ the bio-oil production from macroalga Ulva prolifera sp.; however, the bio-oil contained large quantities of $\mathrm{O}, \mathrm{S}$, and $\mathrm{N}(52.89,3.23$, and $1.43 \mathrm{wt} \%$ respectively) which must be eliminated before it can be used as a fuel. In another research, [166] found that $2.4 \% \mathrm{H}_{2} \mathrm{SO}_{4}$ had a positive effect on the bio-crude oil production from Dunaliella tertiolecta; it can be highlighted that the bio-oil obtained is composed mainly of esters, carboxylic acids, and ketones. In the application of $\mathrm{HCOOH}$ and $\mathrm{CH}_{3} \mathrm{COOH}$ in a reaction with C. vulgaris (300-350 ${ }^{\circ} \mathrm{C}$ for $1 \mathrm{~h}$ ), Ross et al. [152] demonstrated that acid catalyst produced a higher bio-crude oil yield with a better flowability of oil product. Yang et al. [157] obtained a maximum yield of $28 \%$ of bio-oil using $\mathrm{H}_{2} \mathrm{SO}_{4}$ and $\mathrm{CH}_{3} \mathrm{COOH}$ in the catalytic HTL of Enteromorpha prolifera. There are certain challenges that hinder the prospect of industrial application of homogeneous catalysts on HTL. Catalysts based on carbonates (hydroxides or simple carboxylic acids) have a low efficiency on the decarboxylation, isomeration, and aromatization of fatty acids [140]. Formic acid and acetic acid can induce the formation of gas fractions (30 $\mathrm{wt} \%$ and $16-22 \mathrm{wt} \%$, respectively) [152], and are consumed through the reaction stage; therefore, this type of catalyst must be removed and disposed [150]. 


\subsubsection{Heterogeneous Catalysis}

Heterogeneous catalysts, or water-insoluble catalysts, exist in the different phases with liquefaction medium; therefore, they can be recovered and recycled [147]. Another major advantage over homogeneous catalysts is their low corrosion rate and high catalytic activity under severe reaction conditions, which often damage the homogeneous catalysts [139]. Several genera such as Chlorella sp. [154,168-171], Dunaliella sp. [172,173], Nannochloropsis sp. [168,174-176], Spirulina sp. [177-179], Ulva sp. [180], and a mixture of microalgal species [181] have been studied using different heterogeneous catalysts of including supported metal catalysts (such as $\mathrm{Pd}, \mathrm{Pt}, \mathrm{Ni}$, and $\mathrm{Ru}$ ), metal oxide catalyst, and metals supported on $\mathrm{Al}_{2} \mathrm{O}_{3}, \mathrm{SiO}_{2}$, and zeolites. However, the influence of metal catalysts in the biocrude yield is complex, and not all of the evaluated metals can positively improve the yield, even some of them can significantly reduce the overall performance of HTL.

According to the results obtained by Nava Bravo et al. [181], the composition of algal biomass (carbohydrates, lipids, protein, and ash content) and the catalyst play a crucial role in bio-oil yield. In this scenario, bio-oil from $C$. vulgaris was positively affected by $\mathrm{Pt} / \mathrm{Al}_{2} \mathrm{O}_{3}$ and $\mathrm{CoMo} / \mathrm{Al}_{2} \mathrm{O}_{3}$ (from 34 to $39 \mathrm{wt} \%$ ); on the other hand, the bio-oil yield from N. occulata was reduced by each of the three heterogeneous catalysts. Similar results were reported by [174], who evaluated different metal catalysts on Nannochloropsis sp. biomass ( $\mathrm{Pd} / \mathrm{C}$, $\mathrm{Pt} / \mathrm{C}, \mathrm{Ru} / \mathrm{C}, \mathrm{Ni} / \mathrm{SiO}_{2}-\mathrm{Al}_{2} \mathrm{O}_{3}, \mathrm{CoMo} / \gamma-\mathrm{Al}_{2} \mathrm{O}_{3}$, and zeolite). Their results show that metalbased catalysts (especially $\mathrm{Ni} / \mathrm{SiO}_{2}-\mathrm{Al}_{2} \mathrm{O}_{3}$ ) reduce the bio-oil yield. The promotion of gas formation can explain this process by gasification reactions [182]. However, only $\mathrm{Pd} / \mathrm{C}$ effectively increased the bio-oil yield (from 35 to $57 \mathrm{wt} \%$ ). In another study, Yang et al. [173] evaluated the efficiency of REHY and Ni/REHY in D. salina conversion. The results showed an increase of bio-oil yield from $35 \%$ up to 52 and $72 \%$ for REHY and Ni/REHY, respectively. The Ni-based catalyst can improve the overall biomass conversion by catalyzing bond cleavages and the depolymerization process. In another study, Raney-Ni and HZSM5 type zeolite (using ethanol as solvent) were evaluated on the catalytic efficiency over C. pyrenoidosa biomass [182]. The results show that the catalyst does not improve the yield of bio-oil for the different conditions considered. However, the catalyst employed enhanced the concentration of other reaction products such as light fuel-range (gasoline range) hydrocarbons. Other zeolite-based catalysts such as H-ZSM-5 and Ce/H-ZSM-5 have been reported for the conversion of C. pyrenoidosa biomass [171], and their results highlight the efficiency of zeolite-based catalysts, due to a raise in the yield of bio-oil from $32 \%$ to $38 \%$ and $52 \%$ for H-ZSM- 5 and Ce/H-ZSM-5, respectively. Even after all the different research highlighted in the present review, there is no clarity on the underlying mechanism of heterogeneous catalysts in the liquefaction process of algal biomass. According to the literature, heterogeneous catalysts are considered superior to their counterpart; however, there are some conditions that hamper their efficiency. Xu et al. [171] found that biomass impurities such ash and excess of media nutrients can produce catalyst deactivation after a certain period in a continuous operation. It is found that found that a high concentration of S, N, and O derivatives can accelerate the deactivation of heterogeneous catalyst [183-185]. 
Table 3. Strains evaluated and their catalyst.

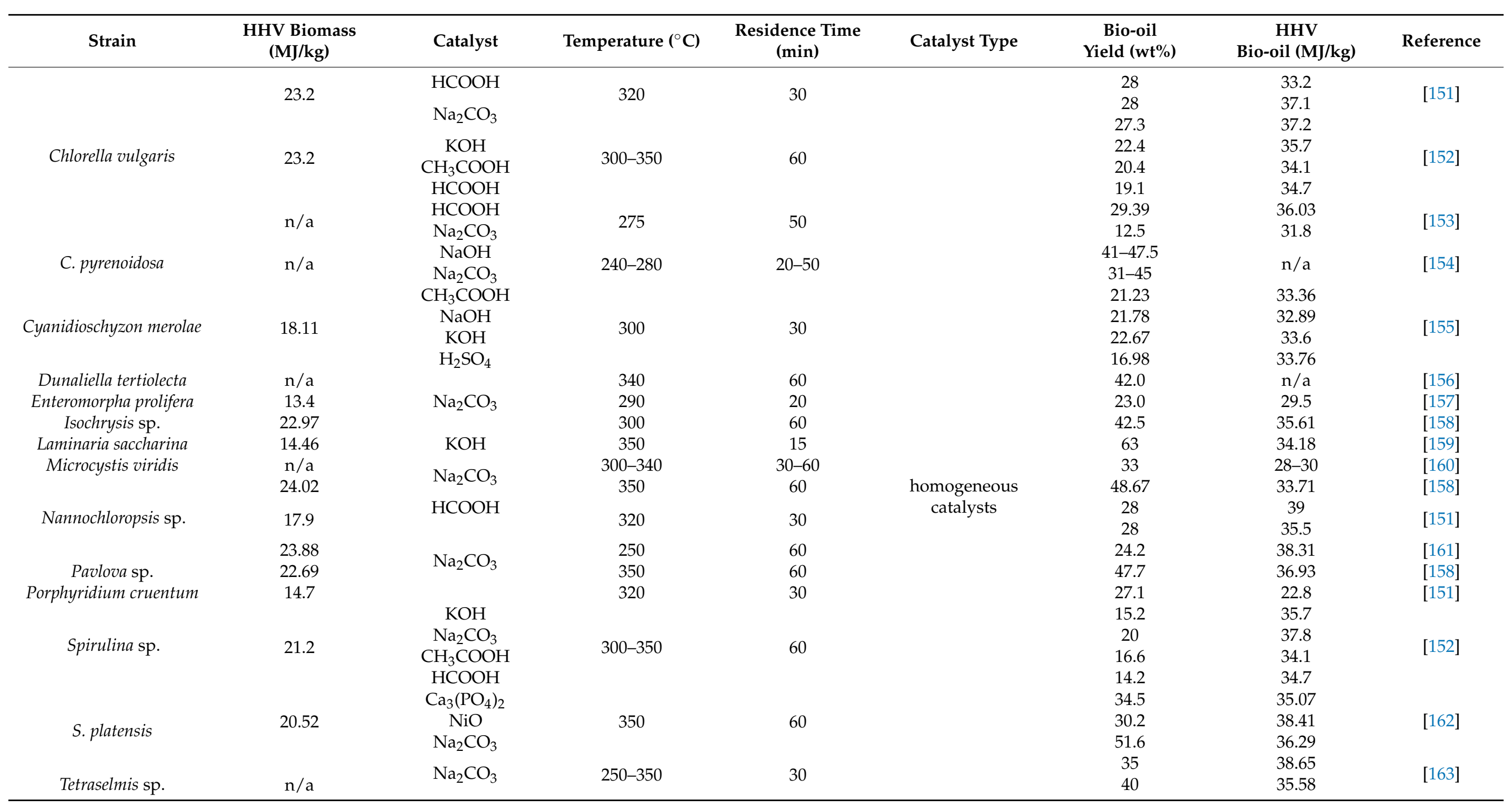


Table 3. Cont.

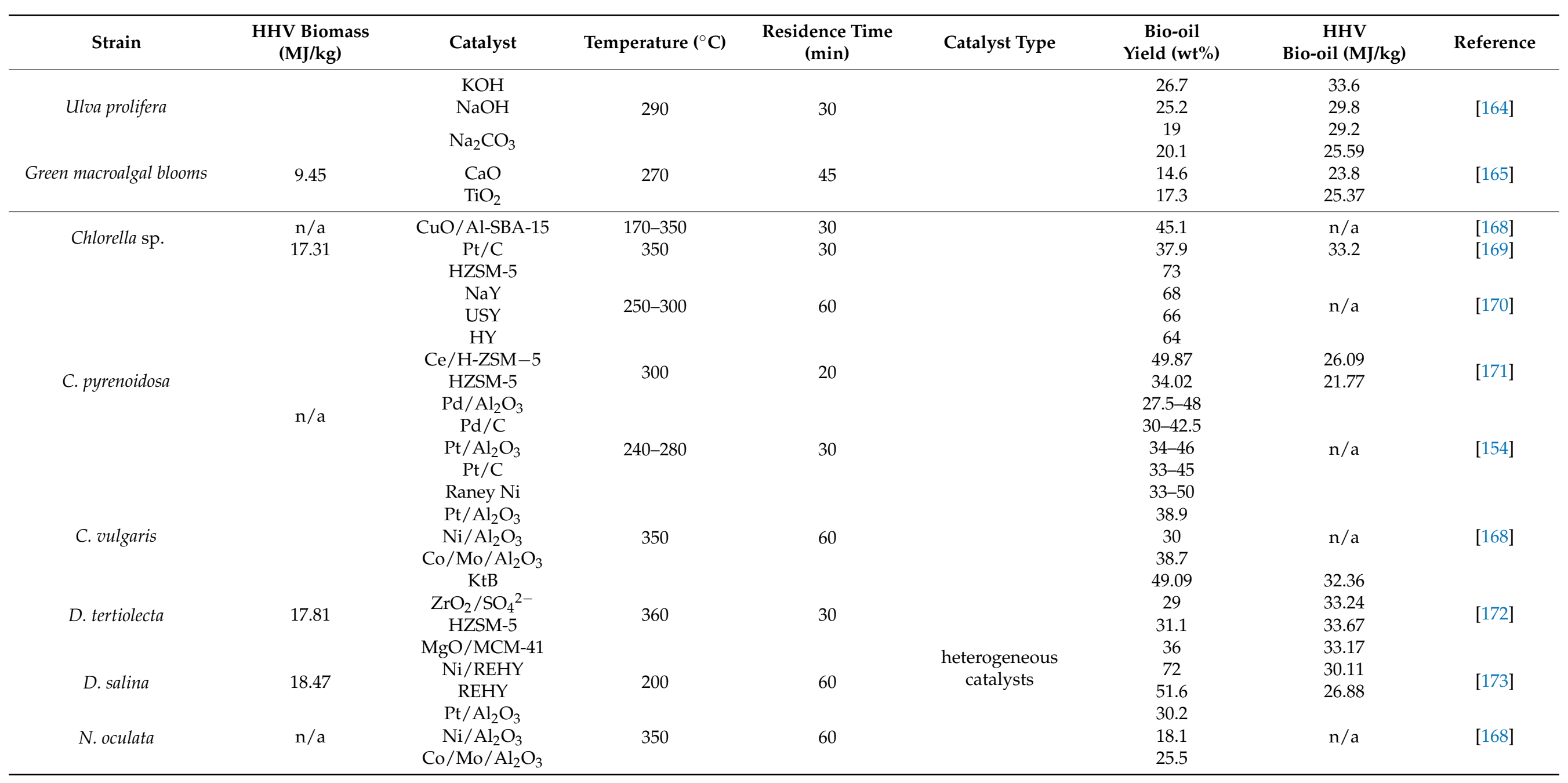


Table 3. Cont.

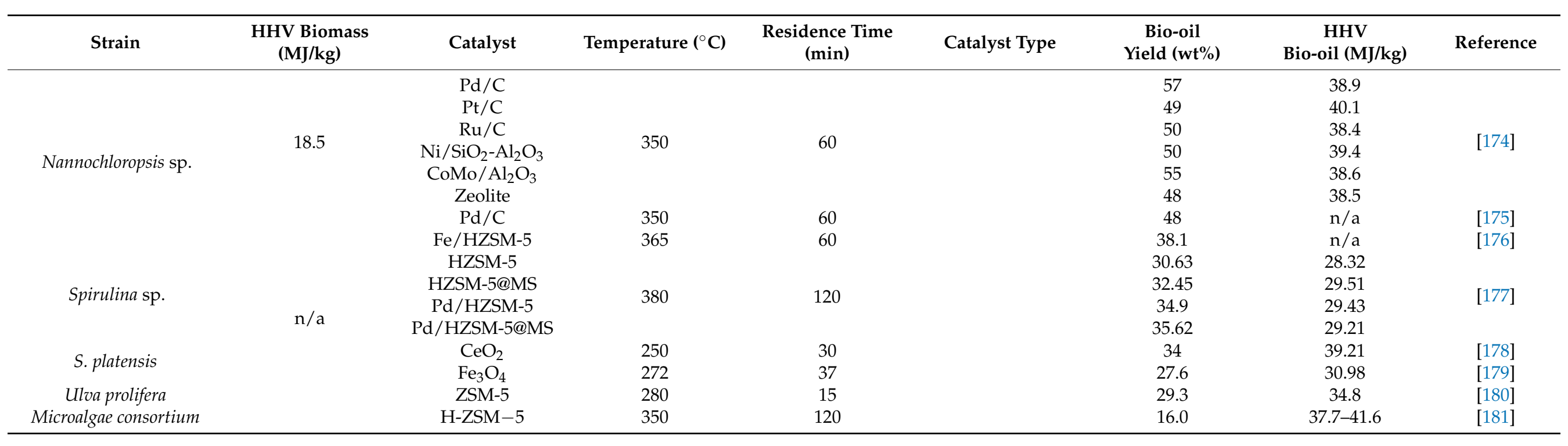




\section{Conclusions}

This paper reviews the experimental aspects of conventional and catalytic thermochemical conversion of microalgal biomass and their product distribution, yields, and quality. The thermochemical conversion of algal biomass is a promising route to obtain alternative fuels for energy generation; however, several challenges must be overcome to increase the sustainability of algal-based biofuels. Torrefaction proved to be an effective pretreatment for algal biomass prior to pyrolysis process; so far, the scientific literature on this pretreatment is still rare, and further research must be done in order to improve its efficiency. Pyrolysis is a well-established technology that shows the right concentration of bio-oil, char, and syngas. Macroalgal biomass can be more interesting for this technology due to the necessity of dried biomass. On the other hand, hydrothermal liquefaction can convert high-moisture biomass to biocrude in water medium and thus does not require preliminary drying processes, which makes HTL the most promising process an energetic point of view for the conversion of algal-based biofuels. The application of catalyst (both homogeneous and heterogeneous) has increased the overall efficiency of conversion of algal biomass in bio-oil, bio-char, and syngas. ZSM-5-based zeolites such as H-ZSM-5, Fe-ZSM-5 Cu-ZSM-5, Ni-ZSM-5, and Ga-HZSM-5 have shown exciting results in the conversion of biomass into bio-oil and bio-char. Therefore, it can be considered the most effective catalyst for the pyrolytic transformation of algal biomass. In HTL reactions, heterogeneous catalysts, specially Pd/C, Ni-based catalyst, and zeolite-based catalyst have shown more consistent data in converting the selected biomass into bio-oil; their recycling ability and low corrosion rate make them a more suitable option. However, particular challenges hinder the prospect of industrial application of catalysts, such as possible corrosion on the reaction equipment, low recycling capacity, and catalyst deactivation after a certain period in a continuous operation. Therefore, designing novel catalysts for the selective conversion of microalgae into biofuels is a mandatory step to increase the efficiency of the process.

Author Contributions: Conceptualization, A.Z.; Data curation, A.F.B.-S. and J.B.G.-M.; Funding acquisition, A.F.B.-S.; Investigation, A.Z. and A.F.B.-S.; Resources, A.Z.; Software, J.B.G.-M. and A.Z.; Supervision, A.F.B.-S. and A.Z.; Writing-original draft, A.F.B.-S. and A.Z.; Writing-review and editing, J.B.G.-M. and A.Z. All authors have read and agreed to the published version of the manuscript.

Funding: This review was partially supported by grants from Sapienza University of Rome (Italy), Gen Foundation with the project "Isolation of thermo-tolerant algae as a novel source of food colorants". UFPS internal Research funding: FINU 27-2019; and Newton Fund Institutional Links, ID 527624805 .

Acknowledgments: We would like to express our sincere gratitude to Gen Foundation, Sapienza University of Rome (Italy) and Universidad Francisco de Paula Santander for providing the equipment for this review and the Colombian Ministry of Science Technology and Innovation MINCIENCIAS for the support to national Ph.D. Doctorates through the Francisco José de Caldas scholarship program.

Conflicts of Interest: The authors declare no conflict of interest.

\section{References}

1. Kosmela:, P.; Kazimierski, P.; Formela, K.; Haponiuk, J.; Piszczyk, Ł. Liquefaction of Macroalgae Enteromorpha Biomass for the Preparation of Biopolyols by Using Crude Glycerol. J. Ind. Eng. Chem. 2017, 56, 399-406. [CrossRef]

2. Chowdhury, H.; Loganathan, B. Third-Generation Biofuels from Microalgae: A Review. Curr. Opin. Green Sustain. Chem. 2019, 20, 39-44. [CrossRef]

3. Garcia-Moscoso, J.L.; Obeid, W.; Kumar, S.; Hatcher, P.G. Flash Hydrolysis of Microalgae (Scenedesmus sp.) for Protein Extraction and Production of Biofuels Intermediates. J. Supercrit. Fluids 2013, 82, 183-190. [CrossRef]

4. Ansah, E.; Wang, L.; Zhang, B.; Shahbazi, A. Catalytic Pyrolysis of Raw and Hydrothermally Carbonized Chlamydomonas Debaryana Microalgae for Denitrogenation and Production of Aromatic Hydrocarbons. Fuel 2018, 228, 234-242. [CrossRef]

5. Costa, J.A.V.; de Freitas, B.C.B.; Lisboa, C.R.; Santos, T.D.; de Fraga Brusch, L.R.; de Morais, M.G. Microalgal Biorefinery from $\mathrm{CO}_{2}$ and the Effects under the Blue Economy. Renew. Sustain. Energy Rev. 2019, 99, 58-65. [CrossRef]

6. Quintero-Dallos, V.; García-Martínez, J.B.; Contreras-Ropero, J.E.; Barajas-Solano, A.F.; Barajas-Ferrerira, C.; Lavecchia, R.; Zuorro, A. Vinasse as a Sustainable Medium for the Production of Chlorella vulgaris UTEX 1803. Water 2019, 11, 1526. [CrossRef] 
7. Lu, W.; Asraful Alam, M.; Liu, S.; Xu, J.; Parra Saldivar, R. Critical Processes and Variables in Microalgae Biomass Production Coupled with Bioremediation of Nutrients and $\mathrm{CO}_{2}$ from Livestock Farms: A Review. Sci. Total Environ. 2020, $716,135247$. [CrossRef]

8. Zuorro, A.; Lavecchia, R.; Maffei, G.; Marra, F.; Miglietta, S.; Petrangeli, A.; Familiari, G.; Valente, T. Enhanced lipid extraction from unbroken microalgal cells using enzymes. Chem. Eng. Trans. 2015, 43, 211-216. [CrossRef]

9. Ananthi, V.; Brindhadevi, K.; Pugazhendhi, A.; Arun, A. Impact of Abiotic Factors on Biodiesel Production by Microalgae. Fuel 2021, 284, 118962. [CrossRef]

10. Castellanos-Estupiñan, M.; Sanchez-Galvis, M.; Garcia-Martinez, J.B.; Barajas-Ferreira, C.; Zuorro, A.; Barajas-Solano, A.F. Design of an Electroflotation System for the Concentration and Harvesting of Freshwater Microalgae. Chem. Eng. Trans. 2018, 64, 1-6. [CrossRef]

11. Zabed, H.M.; Akter, S.; Yun, J.; Zhang, G.; Zhang, Y.; Qi, X. Biogas from Microalgae: Technologies, Challenges and Opportunities. Renew. Sustain. Energy Rev. 2020, 117, 109503. [CrossRef]

12. Raheem, A.; Wan Azlina, W.A.K.G.; Taufiq Yap, Y.H.; Danquah, M.K.; Harun, R. Thermochemical Conversion of Microalgal Biomass for Biofuel Production. Renew. Sustain. Energy Rev. 2015, 49, 990-999. [CrossRef]

13. Chen, W.-H.; Lin, B.-J.; Huang, M.-Y.; Chang, J.-S. Thermochemical Conversion of Microalgal Biomass into Biofuels: A Review. Bioresour. Technol. 2015, 184, 314-327. [CrossRef] [PubMed]

14. Ong, H.C.; Chen, W.-H.; Farooq, A.; Gan, Y.Y.; Lee, K.T.; Ashokkumar, V. Catalytic Thermochemical Conversion of Biomass for Biofuel Production: A Comprehensive Review. Renew. Sustain. Energy Rev. 2019, 113, 109266. [CrossRef]

15. Kargbo, H.; Harris, J.S.; Phan, A.N. “Drop-in” Fuel Production from Biomass: Critical Review on Techno-Economic Feasibility and Sustainability. Renew. Sustain. Energy Rev. 2021, 135, 110168. [CrossRef]

16. Huang, C.-H.; Tan, C.-S. A Review: $\mathrm{CO}_{2}$ Utilization. Aerosol Air Qual. Res. 2014, 14, 480-499. [CrossRef]

17. Hena, S.; Znad, H.; Heong, K.T.; Judd, S. Dairy Farm Wastewater Treatment and Lipid Accumulation by Arthrospira platensis. Water Res. 2018, 128, 267-277. [CrossRef]

18. Polat, E.; Yüksel, E.; Altınbaş, M. Mutual Effect of Sodium and Magnesium on the Cultivation of Microalgae Auxenochlorella protothecoides. Biomass Bioenergy 2020, 132, 105441. [CrossRef]

19. Gouveia, J.D.; Ruiz, J.; van den Broek, L.A.M.; Hesselink, T.; Peters, S.; Kleinegris, D.M.M.; Smith, A.G.; van der Veen, D.; Barbosa, M.J.; Wijffels, R.H. Botryococcus braunii Strains Compared for Biomass Productivity, Hydrocarbon and Carbohydrate Content. J. Biotechnol. 2017, 248, 77-86. [CrossRef]

20. Barajas-Solano, A.F.; Guzmán-Monsalve, A.; Kafarov, V. Effect of Carbon-Nitrogen Ratio for the Biomass Production, Hydrocarbons and Lipids on Botryoccus braunii UIS 003. Chem. Eng. Trans. 2016, 49, 247-252. [CrossRef]

21. Banerjee, S.; Ray, A.; Das, D. Optimization of Chlamydomonas reinhardtii Cultivation with Simultaneous $\mathrm{CO}_{2}$ Sequestration and Biofuels Production in a Biorefinery Framework. Sci. Total Environ. 2020, 143080. [CrossRef] [PubMed]

22. Kao, P.-H.; Ng, I.-S. CRISPRi Mediated Phosphoenolpyruvate Carboxylase Regulation to Enhance the Production of Lipid in Chlamydomonas reinhardtii. Bioresour. Technol. 2017, 245, 1527-1537. [CrossRef] [PubMed]

23. Shin, Y.S.; Jeong, J.; Nguyen, T.H.T.; Kim, J.Y.H.; Jin, E.; Sim, S.J. Targeted Knockout of Phospholipase A2 to Increase Lipid Productivity in Chlamydomonas reinhardtii for Biodiesel Production. Bioresour. Technol. 2019, 271, 368-374. [CrossRef] [PubMed]

24. Gao, F.; Yang, H.-L.; Li, C.; Peng, Y.-Y.; Lu, M.-M.; Jin, W.-H.; Bao, J.-J.; Guo, Y.-M. Effect of Organic Carbon to Nitrogen Ratio in Wastewater on Growth, Nutrient Uptake and Lipid Accumulation of a Mixotrophic Microalgae Chlorella sp. Bioresour. Technol. 2019, 282, 118-124. [CrossRef]

25. Bauer, L.M.; Costa, J.A.V.; da Rosa, A.P.C.; Santos, L.O. Growth Stimulation and Synthesis of Lipids, Pigments and Antioxidants with Magnetic Fields in Chlorella kessleri Cultivations. Bioresour. Technol. 2017, 244, 1425-1432. [CrossRef]

26. Cheng, P.; Chu, R.; Zhang, X.; Song, L.; Chen, D.; Zhou, C.; Yan, X.; Cheng, J.J.; Ruan, R. Screening of the Dominant Chlorella pyrenoidosa for Biofilm Attached Culture and Feed Production While Treating Swine Wastewater. Bioresour. Technol. 2020, 318, 124054. [CrossRef]

27. Alavijeh, R.S.; Karimi, K.; Wijffels, R.H.; van den Berg, C.; Eppink, M. Combined Bead Milling and Enzymatic Hydrolysis for Efficient Fractionation of Lipids, Proteins, and Carbohydrates of Chlorella vulgaris Microalgae. Bioresour. Technol. 2020, $309,123321$. [CrossRef]

28. Estévez-Landazábal, L.L.; Barajas-Solano, A.F.; Barajas-Ferreira, C.; Kafarov, V. Improvement of lipid productivity on Chlorella vulgaris using waste glycerol and sodium acetate. CTF Cienc. Tecnol. Futuro 2013, 5, 113-126. Available online: http:/ / www.scielo. org.co/scielo.php?script=sci_arttext\&pid=S0122-53832013000100009 (accessed on 29 November 2020).

29. Sarayloo, E.; Simsek, S.; Unlu, Y.S.; Cevahir, G.; Erkey, C.; Kavakli, I.H. Enhancement of the Lipid Productivity and Fatty Acid Methyl Ester Profile of Chlorella vulgaris by Two Rounds of Mutagenesis. Bioresour. Technol. 2018, 250, 764-769. [CrossRef]

30. Del Río, E.; García-Gómez, E.; Moreno, J.; Guerrero, M.G.; García-González, M. Microalgae for Oil. Assessment of Fatty Acid Productivity in Continuous Culture by Two High-Yield Strains, Chlorococcum oleofaciens and Pseudokirchneriella subcapitata. Algal Res. 2017, 23, 37-42. [CrossRef]

31. Chinnasamy, S.; Bhatnagar, A.; Hunt, R.W.; Das, K.C. Microalgae Cultivation in a Wastewater Dominated by Carpet Mill Effluents for Biofuel Applications. Bioresour. Technol. 2010, 101, 3097-3105. [CrossRef] [PubMed]

32. Sanchez-Silva, L.; López-González, D.; Garcia-Minguillan, A.M.; Valverde, J.L. Pyrolysis, Combustion and Gasification Characteristics of Nannochloropsis gaditana Microalgae. Bioresour. Technol. 2013, 130, 321-331. [CrossRef] [PubMed] 
33. Xue, J.; Balamurugan, S.; Li, D.-W.; Liu, Y.-H.; Zeng, H.; Wang, L.; Yang, W.-D.; Liu, J.-S.; Li, H.-Y. Glucose-6-Phosphate Dehydrogenase as a Target for Highly Efficient Fatty Acid Biosynthesis in Microalgae by Enhancing NADPH Supply. Metab. Eng. 2017, 41, 212-221. [CrossRef] [PubMed]

34. Priharto, N.; Ronsse, F.; Prins, W.; Carleer, R.; Heeres, H.J. Experimental Studies on a Two-Step Fast Pyrolysis-Catalytic Hydrotreatment Process for Hydrocarbons from Microalgae (Nannochloropsis gaditana and Scenedesmus almeriensis). Fuel Process. Technol. 2020, 206, 106466. [CrossRef]

35. Gupta, S.; Pawar, S.B. An Integrated Approach for Microalgae Cultivation Using Raw and Anaerobic Digested Wastewaters from Food Processing Industry. Bioresour. Technol. 2018, 269, 571-576. [CrossRef]

36. Girard, J.-M.; Roy, M.-L.; Hafsa, M.B.; Gagnon, J.; Faucheux, N.; Heitz, M.; Tremblay, R.; Deschênes, J.-S. Mixotrophic Cultivation of Green Microalgae Scenedesmus Obliquus on Cheese Whey Permeate for Biodiesel Production. Algal Res. 2014, 5, 241-248. [CrossRef]

37. Cuéllar-García, D.J.; Rangel-Basto, Y.A.; Urbina-Suarez, N.A.; Barajas-Solano, A.F.; Muñoz-Peñaloza, Y.A. Lipids production from Scenedesmus obliquus through carbon/nitrogen ratio optimization. J. Phys. Conf. Ser. 2019, 1388, 012043. [CrossRef]

38. Cuéllar-García, D.J.; Rangel-Basto, Y.A.; Barajas-Solano, A.F.; Muñoz-Peñaloza, Y.A.; Urbina-Suarez, N.A. Towards the production of microalgae biofuels: The effect of the culture medium on lipid deposition. BioTechnologia 2019, 100, 273-278. [CrossRef]

39. Andreotti, V.; Solimeno, A.; Rossi, S.; Ficara, E.; Marazzi, F.; Mezzanotte, V.; García, J. Bioremediation of Aquaculture Wastewater with the Microalgae Tetraselmis suecica: Semi-Continuous Experiments, Simulation and Photo-Respirometric Tests. Sci. Total Environ. 2020, 738, 139859. [CrossRef]

40. Srivatsa, S.C.; Li, F.; Bhattacharya, S. Optimization of Reaction Parameters for Bio-Oil Production by Catalytic Pyrolysis of Microalga Tetraselmis suecica: Influence of Ni-Loading on the Bio-Oil Composition. Renew. Energy 2019, 142, 426-436. [CrossRef]

41. Guiza-Franco, L.; Orozco-Rojas, L.G.; Sanchez-Galvis, M.; Garcia-Martinez, J.B.; Barajas-Ferreira, C.; Zuorro, A.; Barajas-Solano, A.F. Production of Chlorella vulgaris Biomass on UV-Treated Wastewater as an Alternative for Environmental Sustainability on High-Mountain Fisheries. Chem. Eng. Trans. 2018, 64, 517-522. [CrossRef]

42. Merchuk, J.C. Chapter 5-Photobioreactor Design; Jacob-Lopes, E., Maroneze, M.M., Queiroz, M.I., Zepka, L.Q., Eds.; Academic Press: Cambridge, MA, USA, 2020; pp. 101-126. [CrossRef]

43. Sanchez-Galvis, E.M.; Cardenas-Gutierrez, I.Y.; Contreras-Ropero, J.E.; García-Martínez, J.B.; Barajas-Solano, A.F.; Zuorro, A. An Innovative Low-Cost Equipment for Electro-Concentration of Microalgal Biomass. Appl. Sci. 2020, 10, 4841. [CrossRef]

44. Garcia-Martinez, B.; Ayala-Torres, E.; Reyes-Gomez, O.; Zuorro, A.; Barajas-Solano, A.; Barajas-Ferreira, C. Evaluation of a Two-Phase Extraction System of Carbohydrates and Proteins from Chlorella vulgaris UTEX 1803. Chem. Eng. Trans. 2016, 49, 355-360. [CrossRef]

45. Kumar, R.; Ghosh, A.K.; Pal, P. Synergy of Biofuel Production with Waste Remediation along with Value-Added Co-Products Recovery through Microalgae Cultivation: A Review of Membrane-Integrated Green Approach. Sci. Total Environ. 2020, 698, 134169. [CrossRef] [PubMed]

46. Zuorro, A.; Malavasi, V.; Cao, G.; Lavecchia, R. Use of cell wall degrading enzymes to improve the recovery of lipids from Chlorella sorokiniana. Chem. Eng. J. 2019, 377, 120325. [CrossRef]

47. Arun, J.; Gopinath, K.P.; SundarRajan, P.; Felix, V.; JoselynMonica, M.; Malolan, R. A Conceptual Review on Microalgae Biorefinery through Thermochemical and Biological Pathways: Bio-Circular Approach on Carbon Capture and Wastewater Treatment. Bioresour. Technol. Rep. 2020, 11, 100477. [CrossRef]

48. Rangel-Basto, Y.A.; García-Ochoa, I.E.; Suarez-Gelvez, J.H.; Zuorro, A.; Barajas-Solano, A.F.; Urbina-Suarez, N.A. The Effect of Temperature and Enzyme Concentration in the Transesterification Process of Synthetic Microalgae Oil. Chem. Eng. Trans. 2018, 64, 331-336. [CrossRef]

49. Kumar, M.; Sun, Y.; Rathour, R.; Pandey, A.; Thakur, I.S.; Tsang, D.C.W. Algae as Potential Feedstock for the Production of Biofuels and Value-Added Products: Opportunities and Challenges. Sci. Total Environ. 2020, 716, 137116. [CrossRef]

50. Demirbas, A. Use of Algae as Biofuel Sources. Energy Convers. Manag. 2010, 51, 2738-2749. [CrossRef]

51. Tripathi, R.; Singh, J.; Thakur, I.S. Characterization of Microalga Scenedesmus sp. ISTGA1 for Potential $\mathrm{CO}_{2} \mathrm{Sequestration}_{\text {and }}$ Biodiesel Production. Renew. Energy 2015, 74, 774-781. [CrossRef]

52. Kumar, M.; Thakur, I.S. Municipal Secondary Sludge as Carbon Source for Production and Characterization of Biodiesel from Oleaginous Bacteria. Bioresour. Technol. Rep. 2018, 4, 106-113. [CrossRef]

53. De Farias Silva, C.E.; Bertucco, A. Bioethanol from Microalgae and Cyanobacteria: A Review and Technological Outlook. Process Biochem. 2016, 51, 1833-1842. [CrossRef]

54. Dragone, G.; Fernandes, B.D.; Abreu, A.P.; Vicente, A.A.; Teixeira, J.A. Nutrient Limitation as a Strategy for Increasing Starch Accumulation in Microalgae. Appl. Energy 2011, 88, 3331-3335. [CrossRef]

55. Ho, S.-H.; Huang, S.-W.; Chen, C.-Y.; Hasunuma, T.; Kondo, A.; Chang, J.-S. Bioethanol Production Using Carbohydrate-Rich Microalgae Biomass as Feedstock. Bioresour. Technol. 2013, 135, 191-198. [CrossRef] [PubMed]

56. El-Dalatony, M.M.; Kurade, M.B.; Abou-Shanab, R.A.I.; Kim, H.; Salama, E.-S.; Jeon, B.-H. Long-Term Production of Bioethanol in Repeated-Batch Fermentation of Microalgal Biomass Using Immobilized Saccharomyces cerevisiae. Bioresour. Technol. 2016, 219, 98-105. [CrossRef] [PubMed]

57. Chen, C.-Y.; Zhao, X.-Q.; Yen, H.-W.; Ho, S.-H.; Cheng, C.-L.; Lee, D.-J.; Bai, F.-W.; Chang, J.-S. Microalgae-Based Carbohydrates for Biofuel Production. Biochem. Eng. J. 2013, 78, 1-10. [CrossRef] 
58. Wang, H.; Ji, C.; Bi, S.; Zhou, P.; Chen, L.; Liu, T. Joint Production of Biodiesel and Bioethanol from Filamentous Oleaginous Microalgae Tribonema sp. Bioresour. Technol. 2014, 172, 169-173. [CrossRef]

59. Talebnia, F.; Karakashev, D.; Angelidaki, I. Production of Bioethanol from Wheat Straw: An Overview on Pretreatment, Hydrolysis and Fermentation. Bioresour. Technol. 2010, 101, 4744-4753. [CrossRef]

60. Baeyens, J.; Kang, Q.; Appels, L.; Dewil, R.; Lv, Y.; Tan, T. Challenges and Opportunities in Improving the Production of Bio-Ethanol. Prog. Energy Combust. Sci. 2015, 47, 60-88. [CrossRef]

61. Hernández, D.; Riaño, B.; Coca, M.; García-González, M.C. Saccharification of Carbohydrates in Microalgal Biomass by Physical, Chemical and Enzymatic Pre-Treatments as a Previous Step for Bioethanol Production. Chem. Eng. J. 2015, 262, 939-945. [CrossRef]

62. Barajas-Solano, A.F.; Gonzalez-Delgado, A.D.; Kafarov, V. Effect of Thermal Pre-Treatment on Fermentable Sugar Production of Chlorella vulgaris. Chem. Eng. Trans. 2014, 37, 655-660. [CrossRef]

63. Rizza, L.S.; Smachetti, M.E.S.; Do Nascimento, M.; Salerno, G.L.; Curatti, L. Bioprospecting for Native Microalgae as an Alternative Source of Sugars for the Production of Bioethanol. Algal Res. 2017, 22, 140-147. [CrossRef]

64. Córdova, O.; Santis, J.; Ruiz-Fillipi, G.; Zuñiga, M.E.; Fermoso, F.G.; Chamy, R. Microalgae Digestive Pretreatment for Increasing Biogas Production. Renew. Sustain. Energy Rev. 2018, 82, 2806-2813. [CrossRef]

65. Jankowska, E.; Sahu, A.K.; Oleskowicz-Popiel, P. Biogas from Microalgae: Review on Microalgae's Cultivation, Harvesting and Pretreatment for Anaerobic Digestion. Renew. Sustain. Energy Rev. 2017, 75, 692-709. [CrossRef]

66. González-Fernández, C.; Sialve, B.; Bernet, N.; Steyer, J.P. Thermal Pretreatment to Improve Methane Production of Scenedesmus Biomass. Biomass Bioenergy 2012, 40, 105-111. [CrossRef]

67. Sialve, B.; Bernet, N.; Bernard, O. Anaerobic Digestion of Microalgae as a Necessary Step to Make Microalgal Biodiesel Sustainable. Biotechnol. Adv. 2009, 27, 409-416. [CrossRef]

68. Anwar, M.; Lou, S.; Chen, L.; Li, H.; Hu, Z. Recent Advancement and Strategy on Bio-Hydrogen Production from Photosynthetic Microalgae. Bioresour. Technol. 2019, 292, 121972. [CrossRef]

69. Jiménez-Llanos, J.; Ramírez-Carmona, M.; Rendón-Castrillón, L.; Ocampo-López, C. Sustainable Biohydrogen Production by Chlorella sp. Microalgae: A Review. Int. J. Hydrogen Energy 2020, 45, 8310-8328. [CrossRef]

70. Gimpel, J.A.; Specht, E.A.; Georgianna, D.R.; Mayfield, S.P. Advances in Microalgae Engineering and Synthetic Biology Applications for Biofuel Production. Curr. Opin. Chem. Biol. 2013, 17, 489-495. [CrossRef]

71. Mathimani, T.; Baldinelli, A.; Rajendran, K.; Prabakar, D.; Matheswaran, M.; Pieter van Leeuwen, R.; Pugazhendhi, A. Review on Cultivation and Thermochemical Conversion of Microalgae to Fuels and Chemicals: Process Evaluation and Knowledge Gaps. J. Clean. Prod. 2019, 208, 1053-1064. [CrossRef]

72. Chen, W.-H.; Peng, J.; Bi, X.T. A State-of-the-Art Review of Biomass Torrefaction, Densification and Applications. Renew. Sustain. Energy Rev. 2015, 44, 847-866. [CrossRef]

73. Wu, K.-T.; Tsai, C.-J.; Chen, C.-S.; Chen, H.-W. The Characteristics of Torrefied Microalgae. Appl. Energy 2012, 100, 52-57. [CrossRef]

74. Cahyanti, M.N.; Doddapaneni, T.R.K.C.; Kikas, T. Biomass Torrefaction: An Overview on Process Parameters, Economic and Environmental Aspects and Recent Advancements. Bioresour. Technol. 2020, 301, 122737. [CrossRef] [PubMed]

75. Bach, Q.-V.; Chen, W.-H.; Lin, S.-C.; Sheen, H.-K.; Chang, J.-S. Effect of Wet Torrefaction on Thermal Decomposition Behavior of Microalga Chlorella vulgaris ESP-31. Energy Procedia 2017, 105, 206-211. [CrossRef]

76. Bach, Q.-V.; Chen, W.-H.; Sheen, H.-K.; Chang, J.-S. Gasification Kinetics of Raw and Wet-Torrefied Microalgae Chlorella vulgaris ESP-31 in Carbon Dioxide. Bioresour. Technol. 2017, 244, 1393-1399. [CrossRef] [PubMed]

77. Uemura, Y.; Matsumoto, R.; Saadon, S.; Matsumura, Y. A Study on Torrefaction of Laminaria japonica. Fuel Process. Technol. 2015, 138, 133-138. [CrossRef]

78. Chen, W.-H.; Huang, M.-Y.; Chang, J.-S.; Chen, C.-Y.; Lee, W.-J. An Energy Analysis of Torrefaction for Upgrading Microalga Residue as a Solid Fuel. Bioresour. Technol. 2015, 185, 285-293. [CrossRef]

79. Yu, K.L.; Chen, W.-H.; Sheen, H.-K.; Chang, J.-S.; Lin, C.-S.; Ong, H.C.; Show, P.L.; Ng, E.-P.; Ling, T.C. Production of Microalgal Biochar and Reducing Sugar Using Wet Torrefaction with Microwave-Assisted Heating and Acid Hydrolysis Pretreatment. Renew. Energy 2020, 156, 349-360. [CrossRef]

80. Yu, K.L.; Chen, W.-H.; Sheen, H.-K.; Chang, J.-S.; Lin, C.-S.; Ong, H.C.; Show, P.L.; Ling, T.C. Bioethanol Production from Acid Pretreated Microalgal Hydrolysate Using Microwave-Assisted Heating Wet Torrefaction. Fuel 2020, 279, 118435. [CrossRef]

81. Brennan, L.; Owende, P. Biofuels from Microalgae-A Review of Technologies for Production, Processing, and Extractions of Biofuels and Co-Products. Renew. Sustain. Energy Rev. 2010, 14, 557-577. [CrossRef]

82. Harman-Ware, A.E.; Morgan, T.; Wilson, M.; Crocker, M.; Zhang, J.; Liu, K.; Stork, J.; Debolt, S. Microalgae as a Renewable Fuel Source: Fast Pyrolysis of Scenedesmus sp. Renew. Energy 2013, 60, 625-632. [CrossRef]

83. Babich, I.V.; van der Hulst, M.; Lefferts, L.; Moulijn, J.A.; O'Connor, P.; Seshan, K. Catalytic Pyrolysis of Microalgae to High-Quality Liquid Bio-Fuels. Biomass Bioenergy 2011, 35, 3199-3207. [CrossRef]

84. Roberts, D.A.; Paul, N.A.; Dworjanyn, S.A.; Bird, M.I.; de Nys, R. Biochar from Commercially Cultivated Seaweed for Soil Amelioration. Sci. Rep. 2015, 5, 9665. [CrossRef] [PubMed]

85. Huang, Y.F.; Lo, S.L. Predicting Heating Value of Lignocellulosic Biomass Based on Elemental Analysis. Energy 2020, $191,116501$. [CrossRef] 
86. Choi, J.H.; Kim, S.-S.; Suh, D.J.; Jang, E.-J.; Min, K.-I.; Woo, H.C. Characterization of the Bio-Oil and Bio-Char Produced by Fixed Bed Pyrolysis of the Brown Alga Saccharina japonica. Korean J. Chem. Eng. 2016, 33, 2691-2698. [CrossRef]

87. Bae, Y.J.; Ryu, C.; Jeon, J.-K.; Park, J.; Suh, D.J.; Suh, Y.-W.; Chang, D.; Park, Y.-K. The Characteristics of Bio-Oil Produced from the Pyrolysis of Three Marine Macroalgae. Bioresour. Technol. 2011, 102, 3512-3520. [CrossRef]

88. Maddi, B.; Viamajala, S.; Varanasi, S. Comparative Study of Pyrolysis of Algal Biomass from Natural Lake Blooms with Lignocellulosic Biomass. Bioresour. Technol. 2011, 102, 11018-11026. [CrossRef]

89. Lee, X.J.; Ong, H.C.; Gan, Y.Y.; Chen, W.H.; Mahlia, T.M.I. State of Art Review on Conventional and Advanced Pyrolysis of Macroalgae and Microalgae for Biochar, Bio-Oil and Bio-Syngas Production. Energy Convers. Manag. 2020, 210, 112707. [CrossRef]

90. Ahmed, A.; Abu Bakar, M.S.; Azad, A.K.; Sukri, R.S.; Phusunti, N. Intermediate Pyrolysis of Acacia cincinnata and Acacia holosericea Species for Bio-Oil and Biochar Production. Energy Convers. Manag. 2018, 176, 393-408. [CrossRef]

91. Kebelmann, K.; Hornung, A.; Karsten, U.; Griffiths, G. Thermo-Chemical Behaviour and Chemical Product Formation from Polar Seaweeds during Intermediate Pyrolysis. J. Anal. Appl. Pyrolysis 2013, 104, 131-138. [CrossRef]

92. Mahmood, A.S.N.; Brammer, J.G.; Hornung, A.; Steele, A.; Poulston, S. The Intermediate Pyrolysis and Catalytic Steam Reforming of Brewers Spent Grain. J. Anal. Appl. Pyrolysis 2013, 103, 328-342. [CrossRef]

93. Yang, Y.; Zhang, Y.; Omairey, E.; Cai, J.; Gu, F.; Bridgwater, A.V. Intermediate Pyrolysis of Organic Fraction of Municipal Solid Waste and Rheological Study of the Pyrolysis Oil for Potential Use as Bio-Bitumen. J. Clean. Prod. 2018, 187, 390-399. [CrossRef]

94. Mohammed, I.Y.; Abakr, Y.A.; Yusup, S.; Kazi, F.K. Valorization of Napier Grass via Intermediate Pyrolysis: Optimization Using Response Surface Methodology and Pyrolysis Products Characterization. J. Clean. Prod. 2017, 142, 1848-1866. [CrossRef]

95. Kebelmann, K.; Hornung, A.; Karsten, U.; Griffiths, G. Intermediate Pyrolysis and Product Identification by TGA and Py-GC/MS of Green Microalgae and Their Extracted Protein and Lipid Components. Biomass Bioenergy 2013, 49, 38-48. [CrossRef]

96. Yang, Y.; Brammer, J.G.; Mahmood, A.S.N.; Hornung, A. Intermediate Pyrolysis of Biomass Energy Pellets for Producing Sustainable Liquid, Gaseous and Solid Fuels. Bioresour. Technol. 2014, 169, 794-799. [CrossRef] [PubMed]

97. Chang, Y.-M.; Tsai, W.-T.; Li, M.-H. Chemical Characterization of Char Derived from Slow Pyrolysis of Microalgal Residue. J. Anal. Appl. Pyrolysis 2015, 111, 88-93. [CrossRef]

98. Wang, K.; Brown, R.C.; Homsy, S.; Martinez, L.; Sidhu, S.S. Fast Pyrolysis of Microalgae Remnants in a Fluidized Bed Reactor for Bio-Oil and Biochar Production. Bioresour. Technol. 2013, 127, 494-499. [CrossRef]

99. Ashokkumar, V.; Chen, W.-H.; Kamyab, H.; Kumar, G.; Al-Muhtaseb, A.H.; Ngamcharussrivichai, C. Cultivation of Microalgae Chlorella sp. in Municipal Sewage for Biofuel Production and Utilization of Biochar Derived from Residue for the Conversion of Hematite Iron Ore $\left(\mathrm{Fe}_{2} \mathrm{O}_{3}\right)$ to Iron (Fe)—Integrated Algal Biorefinery. Energy 2019, 189, 116128. [CrossRef]

100. Woolf, D.; Amonette, J.E.; Street-Perrott, F.A.; Lehmann, J.; Joseph, S. Sustainable Biochar to Mitigate Global Climate Change. Nat. Commun. 2010, 1, 56. [CrossRef]

101. Lavecchia, R.; Medici, F.; Patterer, M.S.; Zuorro, A. Lead removal from water by adsorption on spent coffee grounds. Chem. Eng. Trans. 2016, 47, 295-300. [CrossRef]

102. Nejati, B.; Adami, P.; Bozorg, A.; Tavasoli, A.; Mirzahosseini, A.H. Catalytic Pyrolysis and Bio-Products Upgrading Derived from Chlorella vulgaris over Its Biochar and Activated Biochar-Supported Fe Catalysts. J. Anal. Appl. Pyrolysis 2020, 104799. [CrossRef]

103. Jung, K.-W.; Jeong, T.-U.; Kang, H.-J.; Ahn, K.-H. Characteristics of Biochar Derived from Marine Macroalgae and Fabrication of Granular Biochar by Entrapment in Calcium-Alginate Beads for Phosphate Removal from Aqueous Solution. Bioresour. Technol. 2016, 211, 108-116. [CrossRef] [PubMed]

104. Cai, J.; Wu, W.; Liu, R.; Huber, G.W. A Distributed Activation Energy Model for the Pyrolysis of Lignocellulosic Biomass. Green Chem. 2013, 15, 1331-1340. [CrossRef]

105. Hertzog, J.; Carré, V.; Jia, L.; Mackay, C.L.; Pinard, L.; Dufour, A.; Mašek, O.; Aubriet, F. Catalytic Fast Pyrolysis of Biomass over Microporous and Hierarchical Zeolites: Characterization of Heavy Products. ACS Sustain. Chem. Eng. 2018, 6, 4717-4728. [CrossRef]

106. Li, F.; Srivatsa, S.C.; Bhattacharya, S. A Review on Catalytic Pyrolysis of Microalgae to High-Quality Bio-Oil with Low Oxygeneous and Nitrogenous Compounds. Renew. Sustain. Energy Rev. 2019, 108, 481-497. [CrossRef]

107. Yang, C.; Li, R.; Zhang, B.; Qiu, Q.; Wang, B.; Yang, H.; Ding, Y.; Wang, C. Pyrolysis of Microalgae: A Critical Review. Fuel Process. Technol. 2019, 186, 53-72. [CrossRef]

108. Amin, M.; Chetpattananondh, P.; Ratanawilai, S. Application of Extracted Marine Chlorella Sp. Residue for Bio-Oil Production as the Biomass Feedstock and Microwave Absorber. Energy Convers. Manag. 2019, 195, 819-829. [CrossRef]

109. Jafarian, S.; Tavasoli, A. A Comparative Study on the Quality of Bioproducts Derived from Catalytic Pyrolysis of Green Microalgae Spirulina (Arthrospira) plantensis over Transition Metals Supported on HMS-ZSM5 Composite. Int. J. Hydrogen Energy 2018, 43, 19902-19917. [CrossRef]

110. Andrade, L.A.; Barrozo, M.A.S.; Vieira, L.G.M. Catalytic Solar Pyrolysis of Microalgae Chlamydomonas reinhardtii. Sol. Energy 2018, 173, 928-938. [CrossRef]

111. Campanella, A.; Harold, M.P. Fast Pyrolysis of Microalgae in a Falling Solids Reactor: Effects of Process Variables and Zeolite Catalysts. Biomass Bioenergy 2012, 46, 218-232. [CrossRef]

112. Huang, F.; Tahmasebi, A.; Maliutina, K.; Yu, J. Formation of Nitrogen-Containing Compounds during Microwave Pyrolysis of Microalgae: Product Distribution and Reaction Pathways. Bioresour. Technol. 2017, 245, 1067-1074. [CrossRef] [PubMed] 
113. Wang, K.; Brown, R.C. Catalytic Pyrolysis of Microalgae for Production of Aromatics and Ammonia. Green Chem. 2013, 15, 675-681. [CrossRef]

114. Zainan, N.H.; Srivatsa, S.C.; Li, F.; Bhattacharya, S. Quality of Bio-Oil from Catalytic Pyrolysis of Microalgae Chlorella vulgaris. Fuel 2018, 223, 12-19. [CrossRef]

115. Thangalazhy-Gopakumar, S.; Adhikari, S.; Chattanathan, S.A.; Gupta, R.B. Catalytic Pyrolysis of Green Algae for Hydrocarbon Production Using H+ZSM-5 Catalyst. Bioresour. Technol. 2012, 118, 150-157. [CrossRef] [PubMed]

116. Conti, R.; Pezzolesi, L.; Pistocchi, R.; Torri, C.; Massoli, P.; Fabbri, D. Photobioreactor Cultivation and Catalytic Pyrolysis of the Microalga Desmodesmus communis (Chlorophyceae) for Hydrocarbons Production by HZSM-5 Zeolite Cracking. Bioresour. Technol. 2016, 222, 148-155. [CrossRef] [PubMed]

117. Gong, Z.; Fang, P.; Wang, Z.; Li, Q.; Li, X.; Meng, F.; Zhang, H.; Liu, L. Catalytic Pyrolysis of Chemical Extraction Residue from Microalgae Biomass. Renew. Energy 2020, 148, 712-719. [CrossRef]

118. Aysu, T.; Abd Rahman, N.A.; Sanna, A. Catalytic Pyrolysis of Tetraselmis and Isochrysis Microalgae by Nickel Ceria Based Catalysts for Hydrocarbon Production. Energy 2016, 103, 205-214. [CrossRef]

119. Rahman, N.A.A.; Fermoso, J.; Sanna, A. Effect of Li-LSX-Zeolite on the in-Situ Catalytic Deoxygenation and Denitrogenation of Isochrysis sp. Microalgae Pyrolysis Vapours. Fuel Process. Technol. 2018, 173, 253-261. [CrossRef]

120. Abd Rahman, N.A.; Fermoso, J.; Sanna, A. Stability of Li-LSX Zeolite in the Catalytic Pyrolysis of Non-Treated and Acid Pre-Treated Isochrysis sp. Microalgae. Energies 2020, 13, 959. [CrossRef]

121. Pan, P.; Hu, C.; Yang, W.; Li, Y.; Dong, L.; Zhu, L.; Tong, D.; Qing, R.; Fan, Y. The Direct Pyrolysis and Catalytic Pyrolysis of Nannochloropsis sp. Residue for Renewable Bio-Oils. Bioresour. Technol. 2010, 101, 4593-4599. [CrossRef]

122. Aysu, T.; Sanna, A. Nannochloropsis Algae Pyrolysis with Ceria-Based Catalysts for Production of High-Quality Bio-Oils. Bioresour. Technol. 2015, 194, 108-116. [CrossRef] [PubMed]

123. Qi, P.; Chang, G.; Wang, H.; Zhang, X.; Guo, Q. Production of Aromatic Hydrocarbons by Catalytic Co-Pyrolysis of Microalgae and Polypropylene Using HZSM-5. J. Anal. Appl. Pyrolysis 2018, 136, 178-185. [CrossRef]

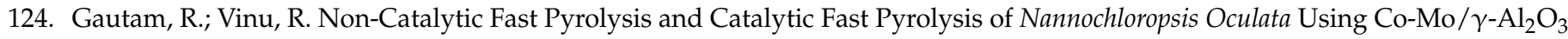
Catalyst for Valuable Chemicals. Algal Res. 2018, 34, 12-24. [CrossRef]

125. Kawale, H.D.; Kishore, N. Production of Hydrocarbons from a Green Algae (Oscillatoria) with Exploration of Its Fuel Characteristics over Different Reaction Atmospheres. Energy 2019, 178, 344-355. [CrossRef]

126. Aysu, T.; Fermoso, J.; Sanna, A. Ceria on Alumina Support for Catalytic Pyrolysis of Pavlova sp. Microalgae to High-Quality Bio-Oils. J. Energy Chem. 2018, 27, 874-882. [CrossRef]

127. Aysu, T.; Ola, O.; Maroto-Valer, M.M.; Sanna, A. Effects of Titania Based Catalysts on In-Situ Pyrolysis of Pavlova Microalgae. Fuel Process. Technol. 2017, 166, 291-298. [CrossRef]

128. Anand, V.; Gautam, R.; Vinu, R. Non-Catalytic and Catalytic Fast Pyrolysis of Schizochytrium limacinum Microalga. Fuel 2017, 205, 1-10. [CrossRef]

129. Mo, L.; Dai, H.; Feng, L.; Liu, B.; Li, X.; Chen, Y.; Khan, S. In-Situ Catalytic Pyrolysis Upgradation of Microalgae into Hydrocarbon Rich Bio-Oil: Effects of Nitrogen and Carbon Dioxide Environment. Bioresour. Technol. 2020, 314, 123758. [CrossRef]

130. Xu, Y.; Hu, Y.; Peng, Y.; Yao, L.; Dong, Y.; Yang, B.; Song, R. Catalytic Pyrolysis and Liquefaction Behavior of Microalgae for Bio-Oil Production. Bioresour. Technol. 2020, 300, 122665. [CrossRef]

131. Suali, E.; Sarbatly, R. Conversion of Microalgae to Biofuel. Renew. Sustain. Energy Rev. 2012, 16, 4316-4342. [CrossRef]

132. Cheng, Y.-T.; Jae, J.; Shi, J.; Fan, W.; Huber, G.W. Production of Renewable Aromatic Compounds by Catalytic Fast Pyrolysis of Lignocellulosic Biomass with Bifunctional Ga/ZSM-5 Catalysts. Angew. Chem. Int. Ed. 2012, 51, 1387-1390. [CrossRef] [PubMed]

133. Du, Z.; Ma, X.; Li, Y.; Chen, P.; Liu, Y.; Lin, X.; Lei, H.; Ruan, R. Production of Aromatic Hydrocarbons by Catalytic Pyrolysis of Microalgae with Zeolites: Catalyst Screening in a Pyroprobe. Bioresour. Technol. 2013, 139, 397-401. [CrossRef] [PubMed]

134. Vichaphund, S.; Aht-ong, D.; Sricharoenchaikul, V.; Atong, D. Production of Aromatic Compounds from Catalytic Fast Pyrolysis of Jatropha Residues Using Metal/HZSM-5 Prepared by Ion-Exchange and Impregnation Methods. Renew. Energy 2015, 79, 28-37. [CrossRef]

135. Naqvi, S.R.; Naqvi, M.; Noor, T.; Hussain, A.; Iqbal, N.; Uemura, Y.; Nishiyama, N. Catalytic Pyrolysis of Botryococcus braunii (Microalgae) Over Layered and Delaminated Zeolites for Aromatic Hydrocarbon Production. Energy Procedia 2017, 142, 381-385. [CrossRef]

136. Belotti, G.; de Caprariis, B.; De Filippis, P.; Scarsella, M.; Verdone, N. Effect of Chlorella vulgaris Growing Conditions on Bio-Oil Production via Fast Pyrolysis. Biomass Bioenergy 2014, 61, 187-195. [CrossRef]

137. Du, Z.; Hu, B.; Ma, X.; Cheng, Y.; Liu, Y.; Lin, X.; Wan, Y.; Lei, H.; Chen, P.; Ruan, R. Catalytic Pyrolysis of Microalgae and Their Three Major Components: Carbohydrates, Proteins, and Lipids. Bioresour. Technol. 2013, 130, 777-782. [CrossRef]

138. Gao, L.; Sun, J.; Xu, W.; Xiao, G. Catalytic Pyrolysis of Natural Algae over Mg-Al Layered Double Oxides/ZSM-5 (MgAlLDO/ZSM-5) for Producing Bio-Oil with Low Nitrogen Content. Bioresour. Technol. 2017, 225, 293-298. [CrossRef]

139. Galadima, A.; Muraza, O. Hydrothermal Liquefaction of Algae and Bio-Oil Upgrading into Liquid Fuels: Role of Heterogeneous Catalysts. Renew. Sustain. Energy Rev. 2018, 81, 1037-1048. [CrossRef]

140. Yang, J.; He, Q.; Yang, L. A Review on Hydrothermal Co-Liquefaction of Biomass. Appl. Energy 2019, 250, 926-945. [CrossRef] 
141. Ponnusamy, V.K.; Nagappan, S.; Bhosale, R.R.; Lay, C.-H.; Duc Nguyen, D.; Pugazhendhi, A.; Chang, S.W.; Kumar, G. Review on Sustainable Production of Biochar through Hydrothermal Liquefaction: Physico-Chemical Properties and Applications. Bioresour. Technol. 2020, 310, 123414. [CrossRef]

142. Chaudry, S.; Bahri, P.A.; Moheimani, N.R. Pathways of Processing of Wet Microalgae for Liquid Fuel Production: A Critical Review. Renew. Sustain. Energy Rev. 2015, 52, 1240-1250. [CrossRef]

143. Xu, D.; Lin, G.; Guo, S.; Wang, S.; Guo, Y.; Jing, Z. Catalytic Hydrothermal Liquefaction of Algae and Upgrading of Biocrude: A Critical Review. Renew. Sustain. Energy Rev. 2018, 97, 103-118. [CrossRef]

144. Guo, Y.; Yeh, T.; Song, W.; Xu, D.; Wang, S. A Review of Bio-Oil Production from Hydrothermal Liquefaction of Algae. Renew. Sustain. Energy Rev. 2015, 48, 776-790. [CrossRef]

145. Tekin, K.; Karagöz, S.; Bektaş, S. A Review of Hydrothermal Biomass Processing. Renew. Sustain. Energy Rev. 2014, 40, 673-687. [CrossRef]

146. Pavlovič, I.; Knez, Ž.; Škerget, M. Hydrothermal Reactions of Agricultural and Food Processing Wastes in Sub- and Supercritical Water: A Review of Fundamentals, Mechanisms, and State of Research. J. Agric. Food Chem. 2013, 61, 8003-8025. [CrossRef]

147. Hu, Y.; Gong, M.; Feng, S.; Xu, C.; Bassi, A. A Review of Recent Developments of Pre-Treatment Technologies and Hydrothermal Liquefaction of Microalgae for Bio-Crude Oil Production. Renew. Sustain. Energy Rev. 2019, 101, 476-492. [CrossRef]

148. Eboibi, B.E.; Lewis, D.M.; Ashman, P.J.; Chinnasamy, S. Influence of Process Conditions on Pretreatment of Microalgae for Protein Extraction and Production of Biocrude during Hydrothermal Liquefaction of Pretreated Tetraselmis sp. RSC Adv. 2015, 5, 20193-20207. [CrossRef]

149. Fu, J.; Yang, C.; Wu, J.; Zhuang, J.; Hou, Z.; Lu, X. Direct Production of Aviation Fuels from Microalgae Lipids in Water. Fuel 2015, 139, 678-683. [CrossRef]

150. Mathimani, T.; Mallick, N. A Review on the Hydrothermal Processing of Microalgal Biomass to Bio-Oil-Knowledge Gaps and Recent Advances. J. Clean. Prod. 2019, 217, 69-84. [CrossRef]

151. Biller, P.; Ross, A.B. Potential Yields and Properties of Oil from the Hydrothermal Liquefaction of Microalgae with Different Biochemical Content. Bioresour. Technol. 2011, 102, 215-225. [CrossRef]

152. Ross, A.B.; Biller, P.; Kubacki, M.L.; Li, H.; Lea-Langton, A.; Jones, J.M. Hydrothermal Processing of Microalgae Using Alkali and Organic Acids. Fuel 2010, 89, 2234-2243. [CrossRef]

153. Hu, Y.; Feng, S.; Yuan, Z.; Xu, C.; Bassi, A. Investigation of Aqueous Phase Recycling for Improving Bio-Crude Oil Yield in Hydrothermal Liquefaction of Algae. Bioresour. Technol. 2017, 239, 151-159. [CrossRef] [PubMed]

154. Yu, G.; Zhang, Y.; Guo, B.; Funk, T.; Schideman, L. Nutrient Flows and Quality of Bio-Crude Oil Produced via Catalytic Hydrothermal Liquefaction of Low-Lipid Microalgae. BioEnergy Res. 2014, 7, 1317-1328. [CrossRef]

155. Muppaneni, T.; Reddy, H.K.; Selvaratnam, T.; Dandamudi, K.P.R.; Dungan, B.; Nirmalakhandan, N.; Schaub, T.; Omar Holguin, F.; Voorhies, W.; Lammers, P.; et al. Hydrothermal Liquefaction of Cyanidioschyzon merolae and the Influence of Catalysts on Products. Bioresour. Technol. 2017, 223, 91-97. [CrossRef] [PubMed]

156. Minowa, T.; Yokoyama, S.; Kishimoto, M.; Okakura, T. Oil Production from Algal Cells of Dunaliella tertiolecta by Direct Thermochemical Liquefaction. Fuel 1995, 74, 1735-1738. [CrossRef]

157. Yang, W.; Li, X.; Liu, S.; Feng, L. Direct Hydrothermal Liquefaction of Undried Macroalgae Enteromorpha prolifera Using Acid Catalysts. Energy Convers. Manag. 2014, 87, 938-945. [CrossRef]

158. Shakya, R.; Whelen, J.; Adhikari, S.; Mahadevan, R.; Neupane, S. Effect of Temperature and $\mathrm{Na}_{2} \mathrm{CO}_{3}$ Catalyst on Hydrothermal Liquefaction of Algae. Algal Res. 2015, 12, 80-90. [CrossRef]

159. Bach, Q.-V.; Sillero, M.V.; Tran, K.-Q.; Skjermo, J. Fast Hydrothermal Liquefaction of a Norwegian Macro-Alga: Screening Tests. Algal Res. 2014, 6, 271-276. [CrossRef]

160. Yang, Y.F.; Feng, C.P.; Inamori, Y.; Maekawa, T. Analysis of Energy Conversion Characteristics in Liquefaction of Algae. Resour. Conserv. Recycl. 2004, 43, 21-33. [CrossRef]

161. Saber, M.; Golzary, A.; Hosseinpour, M.; Takahashi, F.; Yoshikawa, K. Catalytic Hydrothermal Liquefaction of Microalgae Using Nanocatalyst. Appl. Energy 2016, 183, 566-576. [CrossRef]

162. Jena, U.; Das, K.C.; Kastner, J.R. Comparison of the Effects of $\mathrm{Na}_{2} \mathrm{CO}_{3}, \mathrm{Ca}_{3}\left(\mathrm{PO}_{4}\right)_{2}$, and NiO Catalysts on the Thermochemical Liquefaction of Microalga Spirulina platensis. Appl. Energy 2012, 98, 368-375. [CrossRef]

163. Lavanya, M.; Meenakshisundaram, A.; Renganathan, S.; Chinnasamy, S.; Lewis, D.M.; Nallasivam, J.; Bhaskar, S. Hydrothermal Liquefaction of Freshwater and Marine Algal Biomass: A Novel Approach to Produce Distillate Fuel Fractions through Blending and Co-Processing of Biocrude with Petrocrude. Bioresour. Technol. 2016, 203, 228-235. [CrossRef] [PubMed]

164. Yan, L.; Wang, Y.; Li, J.; Zhang, Y.; Ma, L.; Fu, F.; Chen, B.; Liu, H. Hydrothermal Liquefaction of Ulva prolifera Macroalgae and the Influence of Base Catalysts on Products. Bioresour. Technol. 2019, 292, 121286. [CrossRef] [PubMed]

165. Kumar, V.; Kumar, S.; Chauhan, P.K.; Verma, M.; Bahuguna, V.; Joshi, H.C.; Ahmad, W.; Negi, P.; Sharma, N.; Ramola, B.; et al. Low-Temperature Catalyst Based Hydrothermal Liquefaction of Harmful Macroalgal Blooms, and Aqueous Phase Nutrient Recycling by Microalgae. Sci. Rep. 2019, 9, 1-9. [CrossRef] [PubMed]

166. Zou, S.; Wu, Y.; Yang, M.; Li, C.; Tong, J. Thermochemical Catalytic Liquefaction of the Marine Microalgae Dunaliella tertiolecta and Characterization of Bio-Oils. Energy Fuels 2009, 23, 3753-3758. [CrossRef]

167. Zhuang, Y.; Guo, J.; Chen, L.; Li, D.; Liu, J.; Ye, N. Microwave-Assisted Direct Liquefaction of Ulva prolifera for Bio-Oil Production by Acid Catalysis. Bioresour. Technol. 2012, 116, 133-139. [CrossRef] 
168. Li, J.; Fang, X.; Bian, J.; Guo, Y.; Li, C. Microalgae Hydrothermal Liquefaction and Derived Biocrude Upgrading with Modified SBA-15 Catalysts. Bioresour. Technol. 2018, 266, 541-547. [CrossRef]

169. Xu, D.; Guo, S.; Liu, L.; Lin, G.; Wu, Z.; Guo, Y.; Wang, S. Heterogeneous Catalytic Effects on the Characteristics of Water-Soluble and Water-Insoluble Biocrudes in Chlorella Hydrothermal Liquefaction. Appl. Energy 2019, 243, 165-174. [CrossRef]

170. Yang, L.; Ma, R.; Ma, Z.; Li, Y. Catalytic Conversion of Chlorella pyrenoidosa to Biofuels in Supercritical Alcohols over Zeolites. Bioresour. Technol. 2016, 209, 313-317. [CrossRef]

171. Xu, Y.; Zheng, X.; Yu, H.; Hu, X. Hydrothermal Liquefaction of Chlorella pyrenoidosa for Bio-Oil Production over Ce/HZSM-5. Bioresour. Technol. 2014, 156, 1-5. [CrossRef]

172. Chen, Y.; Wu, Y.; Ding, R.; Zhang, P.; Liu, J.; Yang, M.; Zhang, P. Catalytic Hydrothermal Liquefaction of D. tertiolecta for the Production of Bio-Oil over Different Acid/Base Catalysts. AIChE J. 2015, 61, 1118-1128. [CrossRef]

173. Yang, C.; Jia, L.; Chen, C.; Liu, G.; Fang, W. Bio-Oil from Hydro-Liquefaction of Dunaliella salina over Ni/REHY Catalyst. Bioresour. Technol. 2011, 102, 4580-4584. [CrossRef] [PubMed]

174. Duan, P.; Savage, P.E. Hydrothermal Liquefaction of a Microalga with Heterogeneous Catalysts. Ind. Eng. Chem. Res. 2011, 50, 52-61. [CrossRef]

175. Yang, L.; Li, Y.; Savage, P.E. Catalytic Hydrothermal Liquefaction of a Microalga in a Two-Chamber Reactor. Ind. Eng. Chem. Res. 2014, 53, 11939-11944. [CrossRef]

176. Liu, Z.; Li, H.; Zeng, J.; Liu, M.; Zhang, Y.; Liu, Z. Influence of Fe/HZSM-5 Catalyst on Elemental Distribution and Product Properties during Hydrothermal Liquefaction of Nannochloropsis sp. Algal Res. 2018, 35, 1-9. [CrossRef]

177. Liu, C.; Kong, L.; Wang, Y.; Dai, L. Catalytic Hydrothermal Liquefaction of Spirulina to Bio-Oil in the Presence of Formic Acid over Palladium-Based Catalysts. Algal Res. 2018, 33, 156-164. [CrossRef]

178. Kandasamy, S.; Zhang, B.; He, Z.; Chen, H.; Feng, H.; Wang, Q.; Wang, B.; Ashokkumar, V.; Siva, S.; Bhuvanendran, N.; et al Effect of Low-Temperature Catalytic Hydrothermal Liquefaction of Spirulina platensis. Energy 2020, 190, 116236. [CrossRef]

179. Kandasamy, S.; Zhang, B.; He, Z.; Chen, H.; Feng, H.; Wang, Q.; Wang, B.; Bhuvanendran, N.; Esakkimuthu, S.; Ashokkumar, V.; et al. Hydrothermal Liquefaction of Microalgae Using $\mathrm{Fe}_{3} \mathrm{O}_{4}$ Nanostructures as Efficient Catalyst for the Production of Bio-Oil: Optimization of Reaction Parameters by Response Surface Methodology. Biomass Bioenergy 2019, 131, 105417. [CrossRef]

180. Ma, C.; Geng, J.; Zhang, D.; Ning, X. Hydrothermal Liquefaction of Macroalgae: Influence of Zeolites Based Catalyst on Products. J. Energy Inst. 2020, 93, 581-590. [CrossRef]

181. Nava Bravo, I.; Velásquez-Orta, S.B.; Cuevas-García, R.; Monje-Ramírez, I.; Harvey, A.; Orta Ledesma, M.T. Bio-Crude Oil Production Using Catalytic Hydrothermal Liquefaction (HTL) from Native Microalgae Harvested by Ozone-Flotation. Fuel 2019, 241, 255-263. [CrossRef]

182. Zhang, J.; Chen, W.-T.; Zhang, P.; Luo, Z.; Zhang, Y. Hydrothermal Liquefaction of Chlorella pyrenoidosa in Sub- and Supercritical Ethanol with Heterogeneous Catalysts. Bioresour. Technol. 2013, 133, 389-397. [CrossRef] [PubMed]

183. López Barreiro, D.; Prins, W.; Ronsse, F.; Brilman, W. Hydrothermal Liquefaction (HTL) of Microalgae for Biofuel Production: State of the Art Review and Future Prospects. Biomass Bioenergy 2013, 53, 113-127. [CrossRef]

184. Tian, C.; Li, B.; Liu, Z.; Zhang, Y.; Lu, H. Hydrothermal Liquefaction for Algal Biorefinery: A Critical Review. Renew. Sustain. Energy Rev. 2014, 38, 933-950. [CrossRef]

185. Biller, P.; Riley, R.; Ross, A.B. Catalytic Hydrothermal Processing of Microalgae: Decomposition and Upgrading of Lipids. Bioresour. Technol. 2011, 102, 4841-4848. [CrossRef] [PubMed] 